\title{
Chemotaxonomic Significance of Volatile Constituents in Hypenia (Mart. ex Benth.) R. Harley (Lamiaceae)
}

\author{
Julierme G. Silva, ${ }^{a}$ Maria T. Faria,${ }^{b, d}$ Érica R. Oliveira, ${ }^{a}$ Maria H. Rezende, ${ }^{b}$ \\ Dalva G. Ribeiro, ${ }^{d}$ Heleno D. Ferreira, ${ }^{b}$ Suzana C. Santos, ${ }^{a}$ José C. Seraphin ${ }^{c}$ and \\ Pedro H. Ferri ${ }^{*}, a$
}

anstituto de Química, ${ }^{b}$ Instituto de Ciências Biológicas and 'Instituto de Matemática e Estatística, Universidade Federal de Goiás, CP 131, 74001-970 Goiânia-GO, Brazil

'Instituto de Biologia, Universidade de Brasília, CP 4451, 70910-900 Brasília-DF, Brazil

A análise multivariada da composição química dos óleos essenciais de treze espécies de Hypenia indicou a presença de dois grupos de óleos em relação às seções botânicas das amostras. O primeiro grupo (grupo I) incluiu as três espécies da seção Densiflorae em adição a $H$. subrosea e H. aristulata, o qual foi caracterizado pelo maior percentual de $\alpha$-muurolol $(5,85 \pm 3,08 \%)$. No grupo II, com oito espécies da seção Laxiflorae, os principais constituintes discriminantes foram o (E)-cariofileno $(7,09 \pm 4,88 \%)$, germacreno $\mathrm{D}(18,1 \pm 11,4 \%)$ e o biciclogermacreno $(6,65 \pm 1,19 \%)$. Todos os óleos essenciais apresentaram predominantemente sesquiterpenos, tais como espatulenol (4,5-31,6\%), óxido de cariofileno (2,2-14,4\%) e selin-11-en-4 $\alpha$-ol (0-34,8\%). Os agrupamentos foram idênticos quando utilizada a análise multivariada baseada nos esqueletos carbônicos dos constituintes químicos ou de 18 caracteres morfológicos das folhas das espécies.

Multivariate analysis of essential oil compositions of thirteen Hypenia species revealed the presence of two taxonomic clusters. Cluster I included three species belonging to section Densiflorae in addition to $H$. subrosea and $H$. aristulata, and showed the highest percentages of $\alpha$-muurolol $(5.85 \pm 3.08 \%)$. In Cluster II, which contained eight species belonging to section Laxiflorae, the major discriminant constituents were (E)-caryophyllene $(7.09 \pm 4.88 \%)$, germacrene $\mathrm{D}(18.1 \pm 11.4 \%)$, and bicyclogermacrene $(6.65 \pm 1.19 \%)$. All essential oils showed a predominance of sesquiterpenes, such as spathulenol (4.5-31.6\%), caryophyllene oxide (2.2-14.4\%) and selin-11-en- $4 \alpha$-ol (0-34.8\%). Furthermore, identical clusters were revealed by multivariate analysis of chemical constituents based on carbon skeletons, as well as on 18 morphological leaf characters of the species studied.

Keywords: Hypenia, Lamiaceae, essential oil, chemical variability, chemotaxonomy, multivariate analysis

\section{Introduction}

The Lamiaceae family includes approximately 258 genera and 7193 species. Genera such as Salvia and Scutellaria have a wide and cosmopolitan distribution, although lamiaceous plants are especially abundant in the Mediterranean region. ${ }^{1,2}$ In Brazil and other Cerrado areas of eastern South America, the Lamiaceae family is mainly represented by the subtribe Hyptidinae. It is characterized by sternotribic flowers with stamens held in the compressed lower lip of the corolla, which forms an explosive pollination mechanism. ${ }^{2}$ A total of nine genera

*e-mail: pedro@quimica.ufg.br of the neotropical subtribe Hyptidinae are now recognized. Hypenia (Mart. ex Benth.) R. Harley was recently separated from Hyptis Jacq. section Hypenia based largely on number of chromosomes and morphological aspects. ${ }^{2}$

Hypenia contains 27 recognized species on the basis of lax or dense inflorescences including sections Densiflorae Benth. and Laxiflorae Benth. ${ }^{2,3}$ Hypenia species are usually found in oligotrophic and sandy soils with high levels of aluminum, and are distributed over some regions of Venezuela, Bolivia, Paraguay and southern Brazil. In Brazil, they are more common in Cerrado regions where a greater diversity and endemism may be found. Hypenia species are aromatic and are frequently reported in Brazilian Cerrado for their ethnobotanical use, such as the infusion or decoction 
of leaves in the treatment of the flu, common cold and other respiratory diseases. ${ }^{3,4}$ Moderate radical scavenging and antioxidant activities of methanol extracts of the leaves and stems of $H$. salzmannii (Benth.) R. Harley are also reported. ${ }^{5}$

The botanical keys of the two Hypenia sections show that the characters used for their distinction derived almost exclusively from a limited range of floral features. ${ }^{3}$ These difficulties may be partly attributed to the small number of specimens deposited in the herbarium. For example, $H$. paradisi has been collected in only two field trips and H. concinna Benth. is known only from the type species. ${ }^{2,3}$ Since all of them are morphologically and anatomically similar, it is important to find alternative methods of interspecific chemical identification in order to complement analyses of floral traits.

Therefore, this research investigates the chemical constituents of essential oils of thirteen unknown species of Brazilian Hypenia, thus contributing to future taxonomic studies of the genus. We analyzed disability data, as well as species considered rare in Brazil. ${ }^{6}$ In light of the possible chemotaxonomic significance of the oils, results from the chemical analysis were compared with leaf anatomy and taxonomy. For this purpose, essential oils from individuals of representative populations were evaluated by a gas chromatography coupled with mass spectrometer (GC-MS). To study chemical variability, compounds in oil samples and morphological data were submitted to multivariate analysis for determination of taxa distribution patterns and identification of oil constituents, which may be distinguished among the groups of species.

\section{Results and Discussion}

Despite the great diversity of Hypenia species in Brazilian Cerrado areas, the composition of volatile compounds is only known for $H$. salzmannii. ${ }^{7}$ In our study, essential oil compositions were obtained from thirteen species in the inflorescence phenophase, of which three belonged to section Densiflorae (H. brachystachys, $H$. marifolia, $H$. paradise) and ten belonged to section Laxiflorae (H. sphaerocephala, H. durifolia, H. crispata, $H$. reticulata H. macrosiphon, $H$. macrantha, $H$. aristulata, $H$. subrosea and $H$. niquelandiensis). The provenance and voucher specimens are shown in Table S1, at the Supplementary Information (SI).

All Hypenia species investigated contained essential oils ranging from 0.01 to $0.13 \%$ based on dry weight (Table S2). The low oil yields were in agreement with those reported for $H$. salzmannii, which suggests that Hypenia may be a species-poor genus when compared to their rich oil allies, like Hyptis. ${ }^{2,7}$ A total of 85 compounds were identified, accounting for $88-100 \%$ of volatile constituents in the oil samples, and a total of 29 compounds presented an average $\geq 0.5 \%$, accounting for $77-100 \%$ of sampled data. Essential oil compositions revealed a predominance of sesquiterpenes (41.7-97.5\%). High contents of oxygenated sesquiterpenes were present in most species, although hydrocarbons were majority (44.1-54.0\%) in a few taxa belonging to section Laxiflorae. Apart from H. brachystachys and H. marifolia, which showed significant levels of terpenes, aromatic and aliphatic esters (other constituents; 15.44 and $15.00 \%$, respectively), all the other species had lower levels of such compounds $(<4.17 \%)$.

Essential oil compositions of all Hypenia species contained (E)-caryophyllene, $\delta$-cadinene, spathulenol and caryophyllene oxide. The most abundant constituents were: spathulenol (11.27-31.55\%), which showed high average values, with the exception of $H$. marifolia and $H$. niquelandiensis (average value $4.86 \pm 0.52 \%$ ); caryophyllene oxide (6.10-14.38\%), with the exception of $H$. niquelandiensis (2.17\%); and selin-11-en- $4 \alpha$-ol (4.39-34.80\%), with the exception of H. niquelandiensis $(2.12 \%)$ and $H$. marifolia (absent). Germacrene D and bicyclogermacrene were the main constituents in species from section Laxiflorae. All of these results are in agreement with previously described $H$. salzmannii oils (Laxiflorae), which had high levels of (E)-caryophyllene, germacrene D and bicyclogermacrene. ${ }^{7}$ Moreover, Hypenia essential oils showed a wide range of minor constituents.

Despite the fact that the sampling sites featured slightly different soil composition and texture, canonical redundancy analysis revealed no significant correlation between edaphic factors and essential oil chemovariations (data not shown). This result suggests that Hypenia oils were genetically rather than environmentally influenced. Thus, volatile variations may contribute to chemotaxonomic or phylogenetic relationships within the genus. In fact, essential oil polymorphism can help to identify the taxonomic relationships of several Lamiaceae genera, as well as to examine intraspecific variability by processing more than one population per taxon. ${ }^{8}$

In order to assess the use of oil constituents for identifying taxonomic relationships among species, multivariate analysis by principal component analysis (PCA) and nearest neighbour complete linkage cluster-analysis (Ward's method) ${ }^{9}$ were performed with oil constituent levels $\geq 0.5 \%$ $(13$ samples $\times 27$ variables $=351$ data $)$. Figure 1 shows the relative position of the taxa through axial representation based on PCA results. The first PCA accounts for $c a .26 \%$ of the total variance and separates samples well above the $97 \%$ confidence level of the species $H$. aristulata, $H$. paradise and $H$. subrosea from $H$. niquelandiensis. All 


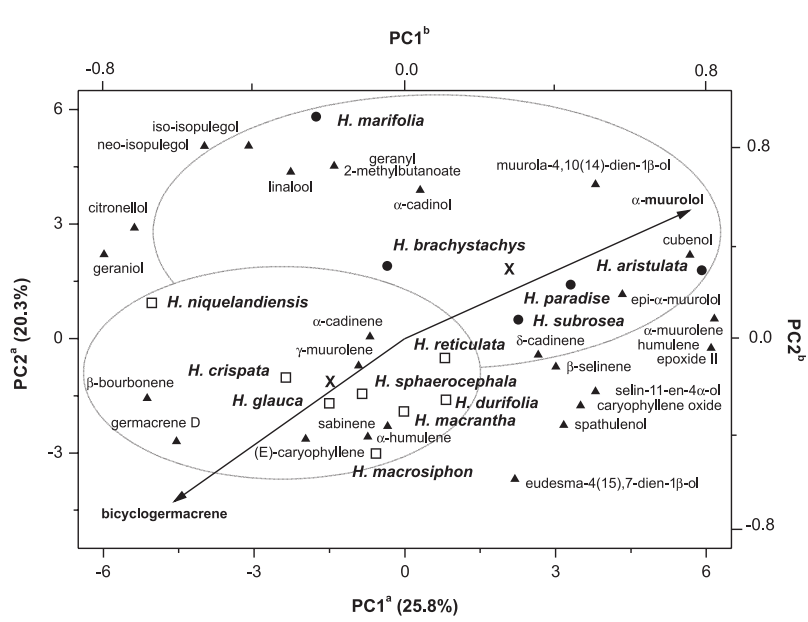

Figure 1. Biplot from PCA of Hypenia spp. essential oil to whose cluster it belongs: I ( $\square$ ); II (O). ${ }^{\mathrm{a} A x e s}$ refer to scores from the samples. ${ }^{\mathrm{b}} \mathrm{Axes}$ refer to loadings from oil constituents represented as shaded triangles (Table S2) and discriminant variables are highlighted as vectors from the origin. Crosses represent cluster centroids and values between parentheses refer to the explained variance on each principal component.

of them are grown in Serra dos Veadeiros (GO, Brazil) and showed the highest $\alpha$-muurolol contents. The second PCA distinguishes $(p<0.005)$ seven species belonging to section Laxiflorae mainly due to highest contents of bicyclogermacrene, germacrene $\mathrm{D}$, and (E)-caryophyllene of H. marifolia and H. brachystachys (Densiflorae section), which are described as monoterpene-rich.

Therefore, two types of essential oils were identified. Cluster I revealed the three species from section Densiflorae (in addition to $H$. subrosea and $H$. aristulata) which were characterized $(p<0.008)$ by the highest percentages of $\alpha$-muurolol $(5.85 \pm 3.08 \%)$. Cluster II revealed eight species of section Laxiflorae containing germacrene $\mathrm{D}(18.1 \pm 11.4 \%)$, (E)-caryophyllene $(7.09 \pm 4.88 \%)$ and bicyclogermacrene $(6.65 \pm 1.19 \%)$ as the main discriminant constituents $(p<0.03)$. Percentages of oil constituents in clustered taxa are shown in the SI (Table S3).

The constituent data were grouped according to carbon skeletons in order to assimilate the overall trend in volatile leaf oils and to decrease the uncontrolled factors affecting quantitative variations (Table S4). As regards the volatile constituents, PCA/cluster analysis on carbon skeletons showed identical differences among these taxa (Figures S1 and S2). Cluster I indicated significant $(p<0.005)$ results concerning the presence of cadinane $(23.1 \pm 10.4 \%)$, copaane $(1.9 \pm 4.3 \%)$, as well as occurrences of isolongifolane, bisabolane and farnesane. Cluster II revealed significant $(p<0.006)$ results for germacrane $(19.6 \pm 11.5 \%)$, bicyclogermacrane $(7.0 \pm 1.2 \%)$ and bourbonane $(2.0 \pm 1.9 \%)$ as the main biosynthetic class (Figures S1 and S2), as well as occurrences of tricyclane, pinane, cedrane and silphiperfolane derivatives (Table S5).
Notwithstanding morphological similarities among Hypenia spp., differences were observed in their leaf morphology. According to Boeger et al.,${ }^{10}$ leaves are one of the most exposed plant organs, which makes them directly influenced by environmental changes. Therefore, they are important elements for the study of a species or of plant communities. Thus, eighteen morphological leaf characters were analyzed in all taxa and coded as independent characters (states present or absent), as recommended by Sneath and Sokal (Table S6). ${ }^{11}$ Multiple correspondence analysis on such taxonomic characters distinguished $\left(\chi^{2}=8.0,5.0\right.$; degrees of freedom, $\left.D F=1,1 ; p<0.025\right)$ clusters I (II) based on the presence or absence of: crystals in small-caliber leaves; starch grains in the pith; and parallel striations on leaf cuticles (Figure S3). Occurrence of calcium oxalate crystals has been related to the mechanical support and protective action against herbivory. ${ }^{12}$ On the other hand, ornamental cuticles have been associated with leaf impermeability and sunlight reflecting, which constitute two important adaptive characteristics of plants in Cerrado regions. ${ }^{13}$

The result most relevant to our study is the agreement between the three assessment procedures (based on chemical and morphological analyses) used for dividing Hypenia into two major groups of species with identical contents. In fact, canonical discriminant analysis (CDA) on chemical data confirmed a priori cluster groups. An axial representation of CDA results discriminated over $99.9 \%$ of the two groups based only on the contents of $\alpha$-muurolol and bicyclogermacrene (predictor variables). Discriminant function analysis explained the overall variability $(F$-test value $=43.198 ; D F=2$ and $10 ; p<0.0001$ ). It was also possible to make an accurate prediction of total wellclassification in the original clusters by cross-validation or Jackknife approach. ${ }^{14}$ These techniques consider a slightly reduced number of samples from the parent data set, estimate parameters from each of these modified data sets, and then calculate the precision of predictions for the samples previously removed by the resulting models. ${ }^{15}$ All similarities between sampled oil constituents and morphological characters are shown in the dendrogram in Figure 2.

These results indicate the presence of two Hypenia sections due to remarkable differences in morphological characters and essential oil compositions. Furthermore, we concluded that the sectional delimitation of $H$. subrosea and $H$. aristulata in the Laxiflorae section should be revised. Differences in volatile constituents among Hypenia spp. may be useful for understanding phylogenetic relationships, especially considering that its species are not easily identified. 

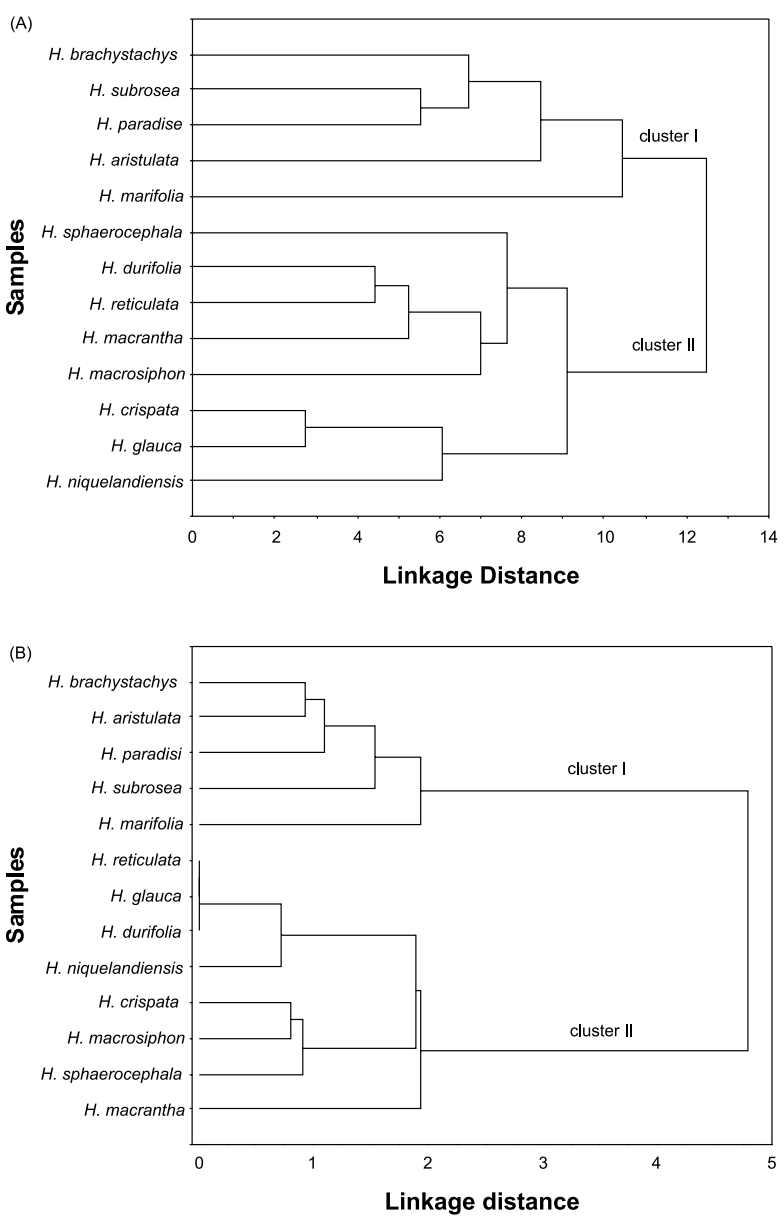

Figure 2. Dendrogram representing the similarity relationships among Hypenia spp. based on (A) essential oil constituents or (B) taxonomic leaf characters to whose cluster it belongs: I and II.

\section{Conclusions}

Essential oil analysis and the morphological and anatomical leaf characteristics of thirteen Hypenia species found in central Brazilian Cerrado areas (GO, Brazil) revealed high polymorphism, which may be related to genetic influences. Furthermore, the two clusters of constituents were in agreement with the division of species into two taxonomic sections.

\section{Experimental}

\section{Plant material}

Hypenia spp. inflorescence samples were collected between May 2006 and November 2007 in Goiás State, Brazil. The specimens were identified by Dr. Raymond M. Harley, and voucher specimens were deposited at the UFG herbarium (conservation unit of Universidade Federal de Goiás, Goiás State, Brazil). A list of the taxa investigated as well as provenance and voucher specimens are shown in Table S1.

To assess essential oil chemical compositions, 5-10 individuals of each species originated from 2-3 populations were pooled and dried at room temperature for 7 days at $30{ }^{\circ} \mathrm{C}$ until constant weight was achieved. After having been powdered, the dried phytomass (5-30 g) of each sample was submitted to hydrodistillation $(2 \mathrm{~h})$ using a modified Clevenger-type apparatus. At the end of each distillation, the oils were collected and dried with anhydrous $\mathrm{Na}_{2} \mathrm{SO}_{4}$, then transferred to glass flasks where they were kept at a temperature of $-18{ }^{\circ} \mathrm{C}$. Oil yields (\%) were based on the dried weight of plant samples.

Soil samples were collected at a depth of $20 \mathrm{~cm}$ in all sampling sites and were collected around each population and pooled together to form a composite sample for each site. After that, they were air-dried, thoroughly mixed, and sieved $(2 \mathrm{~mm}$ ). The portion finer than $2 \mathrm{~mm}$ was kept for physical and chemical analysis. The $\mathrm{pH}$ was determined in a $1: 1 \mathrm{soil} /$ water volume ratio. $\mathrm{Ca}, \mathrm{Mg}$ and $\mathrm{Al}$ were extracted with $\mathrm{KCl} 1 \mathrm{~mol} \mathrm{~L}^{-1}$, whereas $\mathrm{P}, \mathrm{K}, \mathrm{Zn}, \mathrm{Cu}, \mathrm{Fe}$ and $\mathrm{Mn}$ were extracted with Mehlich solution. Organic matter, cationic exchange capacity (CEC), potential acidity $(\mathrm{H}+\mathrm{Al})$, and soil texture were determined by the usual methods. ${ }^{16}$

\section{Morphological and anatomical analyses}

The leaf variations among the thirteen specimens were recorded using a Zeiss-Axioskop light microscope and a Jeol JSM 840A scanning electron microscope operated at $10 \mathrm{kV}$. A list of two-state qualitative characters is presented in Table S5. Fully developed leaves of approximately equal tickness were selected for the study of cross-sectional anatomy. They were cut into segments and fixed for $12 \mathrm{~h}$ in a $2 \%$ glutaraldehyde-paraformaldehyde solution with $0.05 \mathrm{~mol} \mathrm{~L}^{-1}$ sodium cacodylate buffer (pH 7.2). Segments were post fixed in $\mathrm{OsO}_{4}-\mathrm{K}_{3}\left[\mathrm{Fe}(\mathrm{CN})_{6}\right]$ and dehydrated in a water-acetone series. All sections were mounted on grids coated with a layer of gold $(40 \mathrm{~nm})$ and were viewed with a scanning electron microscope. Thicker sections of the same material were also cut, dried and stained with $0.1 \%$ basic fuchsine and $0.3 \%$ astra blue (1:3) for $3 \mathrm{~min}$. Then, they were rinsed, dried again and placed under cover slips with a permanent mounting medium for light microscopy.

Leaves were also cleared and stained for paradermal viewing. Fresh leaf material was placed in a beaker containing boiling $80 \%(\mathrm{v} / \mathrm{v})$ ethanol until the chlorophyll was extracted. It was then put in $10 \%$ aqueous $\mathrm{NaOH}$ solution and left to clear. After that, it was rinsed in distilled water and stained in $1 \%$ safranin solution. Stained 
tissue was placed on a glass slide in water, covered with a cover slip and examined under the light microscope.

\section{Chemical analyses}

Oil sample analyses were performed on a GC-MS (gas chromatography coupled with mass spectrometer) Shimadzu QP5050A instrument under the following conditions: a column CBP-5 (Shimadzu) fused silica capillary column $(30 \mathrm{~m} \times 0.25 \mathrm{~mm}$ i.d., $0.25 \mathrm{~mm}$ film thickness) connected to a quadrupole detector operating in the $\mathrm{EI}$ mode at $70 \mathrm{eV}$ with a scan mass range of $40-400 \mathrm{~m} / \mathrm{z}$ at a sampling rate of $1.0 \mathrm{scan} \mathrm{s}^{-1}$; carrier gas: He $\left(1 \mathrm{~mL} \mathrm{~min}^{-1}\right)$; injector and interface temperatures of 220 and $240{ }^{\circ} \mathrm{C}$, respectively, with a split ratio of 1:20. The injection volume was $0.4 \mathrm{~mL}$ ( $20 \%$ in hexane) and the oven temperature was raised from 60 to $246{ }^{\circ} \mathrm{C}$ with an increase of $3{ }^{\circ} \mathrm{C} \mathrm{min}^{-1}$, then $10^{\circ} \mathrm{C} \mathrm{min}^{-1}$ to $270^{\circ} \mathrm{C}$, holding the final temperature for $5 \mathrm{~min}$. Individual components were identified by a comparison of linear retention indices, ${ }^{17}$ which were determined by a co-injection with a $\mathrm{C}_{8}-\mathrm{C}_{32}$ n-alkanes series, ${ }^{18}$ co-injection with standard, ylang-ylang (Cananga odorata (Lam.) Hook. F. \& Thoms., Annonaceae) and sage clary (Salvia sclarea L., Lamiaceae) essential oils, ${ }^{17}$ mass spectra with those of the literature and a computerized NIST MS database. ${ }^{17}$

\section{Statistical analyses}

Principal component (PCA) and multiple correspondence (MCA) analysis were applied in order to examine the interrelationships between plant taxa, chemical constituents and leaf taxonomic characters (presence/absence status). For these procedures we used Système Portable d'Analyse des Données-SPAD software package. ${ }^{19}$ Cluster analysis was also applied to the study of similarities between species by considering essential oil constituents or taxonomic character distributions. Nearest neighbor complete linkage technique by Benzécri algorithm was used as an index of similarity, ${ }^{20}$ and hierarchical clustering was performed according to Ward's variance minimizing method. ${ }^{9}$ Oil constituents with arbitrated amounts $\geq 0.5 \%$ to the chemical profiles (average values) were initially kept in the original matrix. For variable selection, the threshold of residual eigenvalues $(\leq 0.70)$ in the data matrix was used to establish the maximum number of variables that could be removed. The two variables, which were effectively eliminated, revealed the highest loadings in the lowest residual eigenvalues. Prior to the multivariate analysis, the final data matrix $(13$ samples $\times 27$ variables $=351$ data $)$ was processed by means of auto-scaling and mean centering. Oil constituents were also grouped according to biosynthetic class. The normalized data matrix $(13$ samples $\times 21$ variables $=273$ data $)$ without variable selection was submitted to multivariate analysis (Table S5).

Canonical discriminant analysis using SAS CANDISC procedure $^{21}$ was used to differentiate between taxa and clusters on the basis of oil composition. The predictive ability of canonical discriminant function was evaluated by cross-validation and Jackknife approaches as implemented in SAS statistical package.

Canonical redundancy analysis (RDA) was applied to describe the patterns of the only explained variation of interrelationships between oil composition and the interspecific variations as a function of soil parameters, treated as environmental variables. An unrestricted Monte-Carlo permutation test (1000 permutations) was used to test eigenvalue significance of the first three canonical axes. ${ }^{22}$ RDA was performed in CANOCO software. ${ }^{23}$

Multiple comparisons were established by univariate analysis of variance (ANOVA) using SAS GLM procedure. ${ }^{24}$ All data were checked for homoscedasticity with the use of Hartley's test. This test revealed significant departures from the basic assumption for the oil components, which were arcsine and rank-transformed when necessary. Whenever a difference was established, a Tukey's post-hoc test was performed. Results are indicated by mean values and are joined by the standard deviation of independent measurements. $P$-values below 0.05 were regarded as significant.

\section{Supplementary Information}

Supplementary data are available free of charge at http://jbcs.sbq.org.br as a PDF file.

\section{Acknowledgements}

We thank Dr R. M. Harley for her kind assistance with the botanical identification. The authors are also indebted to CNPq, PADCT III and FUNAPE/UFG for financial support; CAPES for fellowship to M. T. F. and J. G. S.

\section{References}

1. The Angiosperm Phylogeny Group (APG II); Bot. J. Linn. Soc. 2003, 141, 399.

2. Harley, R. M.; Atkins, S.; Budantsev, A. L.; Cantino, P. D.; Conn, B. J.; Grayer, R.; Harley, M. M.; De Kok, R.; Krestovskaja, T.; Morales, R.; Paton, A. J.; Ryding, O.; Upson, T. In The Families and Genera of Vascular Plants, vol. 7; Kubitzki, K.; Kadereit, J. W., eds., Springer-Verlag: Berlin, 2004, chapter 11; Harley, 
R. M.; Reynolds, T.; Advances in Labiatae Science, vol. 98, The Royal Botanic Gardens: Kiew, 1992; Harley, R. M.; Bot. J. Linn. Soc. 1988, 98, 87.

3. Epling, C.; Rev. Museo La Plata, Sección Botânica 1949, 30, 153.

4. Agra, M. F.; Baracho, G. S.; Nurit, K.; Basílio, I. J. L. D.; Coelho, V. P. M.; J. Ethnopharmacol. 2007, 111, 383.

5. David, J. P.; Meira, M.; David, J. M.; Brandão, H. N.; Branco, A.; Agra, M. F.; Barbosa, M. R. V.; Queiroz, L. P.; Giulietti, A. M.; Fitoterapia 2007, 78, 215.

6. Harley, R. M.; França, F. In Plantas Raras do Brasil; Giulietti, A. M.; Rapini, A.; Andrade, M. J. G.; Queiroz, L. P.; Silva, J. M. C., eds., Conservação Internacional: Belo Horizonte, Brasil, 2009; Ministry of Environment of Brazil, Normative statement (annexes I and II) 2008, 6, 3, available: http://www. mp.rs.gov.br/ambiente/legislacao/id4902.html accessed in December 2010; Scarano, F. R.; Martinelli, G.; Braz. J. Nat. Conserv. 2010, 8, 13.

7. Evangelino, T. S.; Ribeiro, A. S.; Nogueira, P. C. L.; Moraes, V. R. S.; Machado, S. M. F.; Alves, P. B.; abstract of the $30^{a}$ Reunião Anual da Sociedade Brasileira de Química, PN-271, 2007 (available: https://sec.sbq.org.br/cdrom/30ra/resumos/ T1979-1.pdf accessed in December 2010); Rocha, S. A. S.; Pessoa, O. D. L.; Mendes, K. G.; Chagas, P. F.; Diniz, J. C.; Viana, F. A.; abstract of the $30^{a}$ Reunião Anual da Sociedade Brasileira de Química, PN-294, 2007 (available: https://sec.sbq. org.br/cdrom/30ra/resumos/T0617-2.pdf accessed in December 2010).

8. Bezic, N.; Samanic, I.; Dunkic, V.; Besendorfer, V.; Puizina, J.; Molecules 2009, 14, 925; Oliveira, M. J.; Campos, I. F. P.; Oliveira, C. B. A.; Santos, M. R.; Souza, P. S.; Santos, S. C., Seraphin, J. C.; Ferri, P. H.; Biochem. Syst. Ecol. 2005, 33, 275; Skaltsa, H. D.; Mavrommati, A.; Constantinidis, T.; Phytochemistry 2001, 57, 235.

9. Ward, J. H.; J. Am. Stat. Assoc. 1963, 58, 238.

10. Boeger, M. R. T.; Alves de Brito, C. J. F.; Negrelle, R. R. B.; Arq. Biol. Tecnol. 1997, 40, 493.

11. Sneath, P. H.; Sokal, R. R.; Principles of Numerical Taxonomy, W.H. Freeman: San Francisco, 1963.

12. Franceschi, V. R.; Horner Jr., H. T.; Bot. Rev. 1980, 46, 361; Metcalfe, C. R.; Chalk, L.; Anatomy of the Dycotyledons, vol. 11, Claredon Press: Oxford, 1983.
13. Esau, K.; Anatomia das Plantas com Sementes; Edgard Blucher: São Paulo, Brasil, 1977; Juniper, B. E.; Jeffree, C. E.; Plant Surfaces, Wards Arnold: London, 1983.

14. Quenouille, M. H.; Biometrika 1956, 43, 353.

15. Wold, A.; Eriksson, L.; Chemometric Methods in Molecular Design; Waterbeemd, H., ed.; In Methods and Principles in Medicinal Chemistry, VCH: Weinheim, 1995, chapter 5, vol. 2.

16. Silva, S. C.; Manual de Análises Químicas de Solos, Plantas e Fertilizantes, 1a. ed.; Embrapa: Brasília, Brasil, 1999.

17. Adams, R. P.; Identification of Essential Oil Components by Gas Chromatography/Mass Spectrometry, $4^{\text {th }}$ ed.; Allured: Illinois, 2007; National Institute of Standards and Technology; PC version of the NIST/EPA/NIH Mass Spectral Database; U.S. Department of Commerce, Gaithersburg, 1998; Kubeczka, K.-H.; Formáček, V.; Essential Oils Analysis by Capillary Gas Chromatography and Carbon-13 NMR Spectroscopy, $2^{\text {nd }}$ ed.; John Wiley \& Sons: New York, 2002.

18. Van Den Dool, H.; Kratz, P. D.; J. Chromatogr. 1963, 11, 463.

19. Système Portable d'Analyse des Données-SPAD software package, version 5.5, Centre International de Statistique et d'Informatique Appliquées, France, 2002.

20. Benzécri, J. P.; L'Analyse des Données: la Taxinomie, Tome 1, Dunod: Paris, 1980.

21. SAS CANDISC Statistical Analysis System, SAS Institute Inc., Cary, NC, 1996.

22. Lepš, J.; Šmilauer, P.; Multivariate Analysis of Ecological Data Using CANOCO, Cambridge University Press: Cambridge, 2007; Jongman, R. H. G.; Ter Braak, C. J. F.; Van Tongeren, O. F. R.; Data Analysis in Community and Landscape Ecology, Cambridge University Press: Cambridge, 2002.

23. Ter Braak, C. J. F.; Šmilauer, P.; CANOCO Reference Manual and CanoDraw for Windows User's Guide: Software for Canonical Community Ordination (version 4.5), Microcomputer Power, New York, 2002.

24. SAS GLM Statistical Analysis System, SAS Institute Inc., Cary, NC, 1996.

Submitted: July 22, 2010

Published online: February 8, 2011 


\section{Chemotaxonomic Significance of Volatile Constituents in Hypenia (Mart. ex Benth.) R. Harley (Lamiaceae)}

Julierme G. Silva, ${ }^{a}$ Maria T. Faria, ${ }^{b, d}$ Érica R. Oliveira, ${ }^{a}$ Maria H. Rezende, ${ }^{b}$ Dalva G. Ribeiro, ${ }^{d}$ Heleno D. Ferreira, ${ }^{b}$ Suzana C. Santos, ${ }^{a}$ José C. Seraphin ${ }^{c}$ and Pedro H. Ferri ${ }^{*}, a$

${ }^{a}$ Instituto de Química, ${ }^{b}$ Instituto de Ciências Biológicas and Instituto de Matemática e Estatística, Universidade Federal de Goiás, CP 131, 74001-970 Goiânia-GO, Brazil 'Instituto de Biologia, Universidade de Brasília, CP 4451, 70910-900 Brasília-DF, Brazil

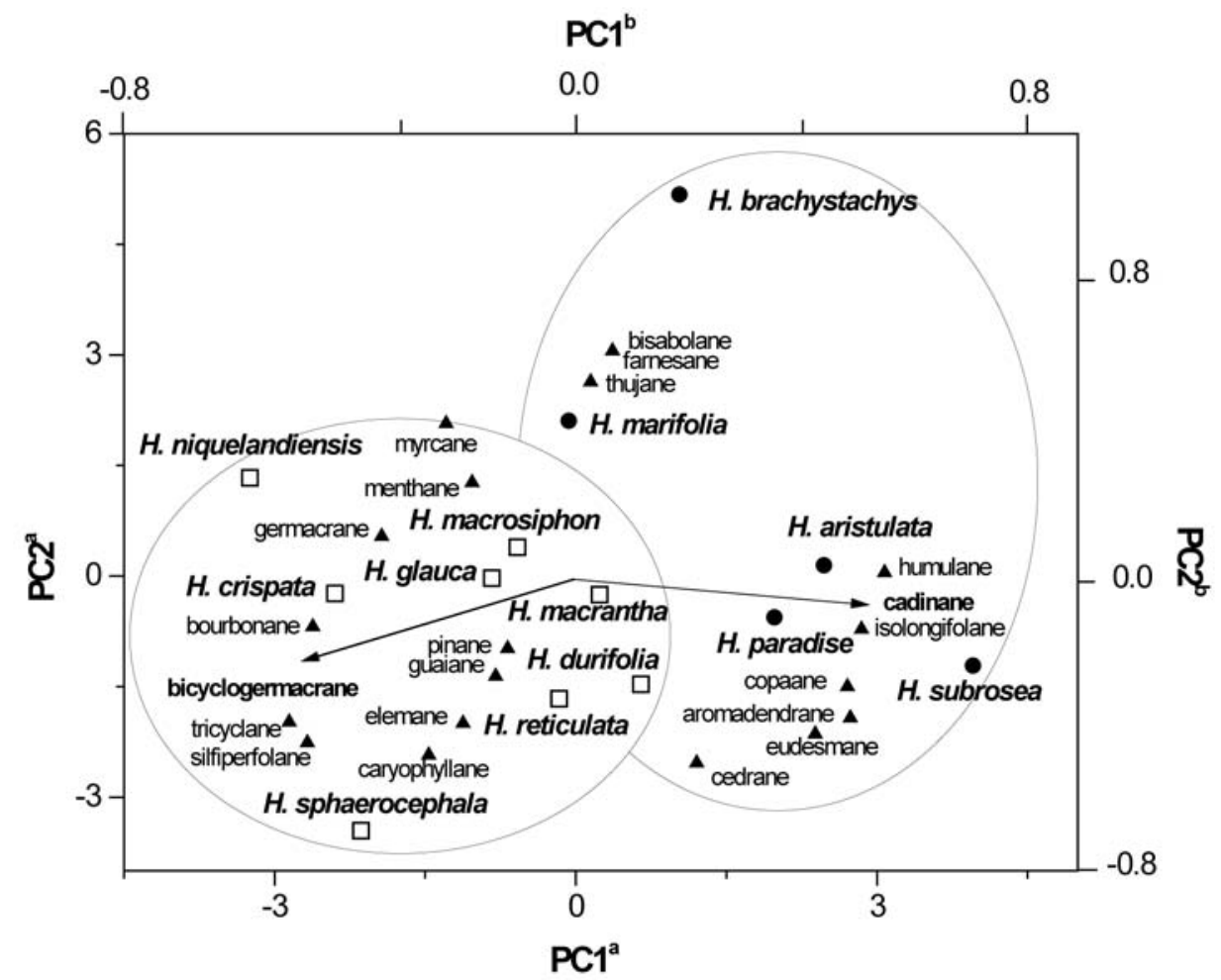

Figure S1. Biplot originating by PCA of Hypenia spp. based on carbon skeletons of volatiles to whose cluster it belongs: I ( $\square$ ); II ( $\left({ }^{a}\right.$ Axes refer to scores from the samples. ${ }^{b}$ Axes refer to loadings from carbon skeletons of oil constituents (Table S4) represented as shaded triangles, and discriminant variables are highlighted as vectors from the origin. 


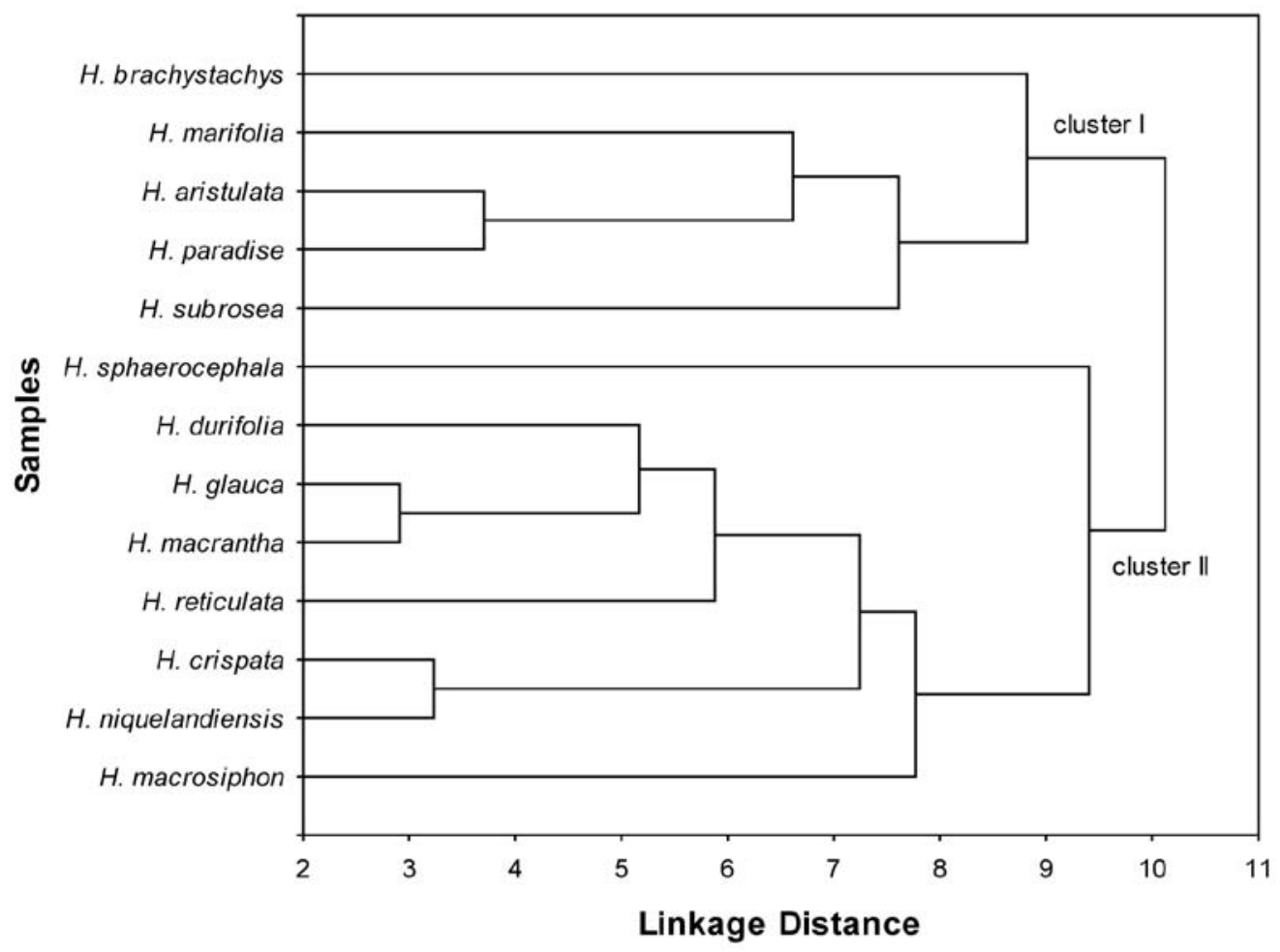

Figure S2. Dendrogram representing the similarity relationships among Hypenia spp. based on carbon skeleton of volatile constituents belonging to clusters I and II.

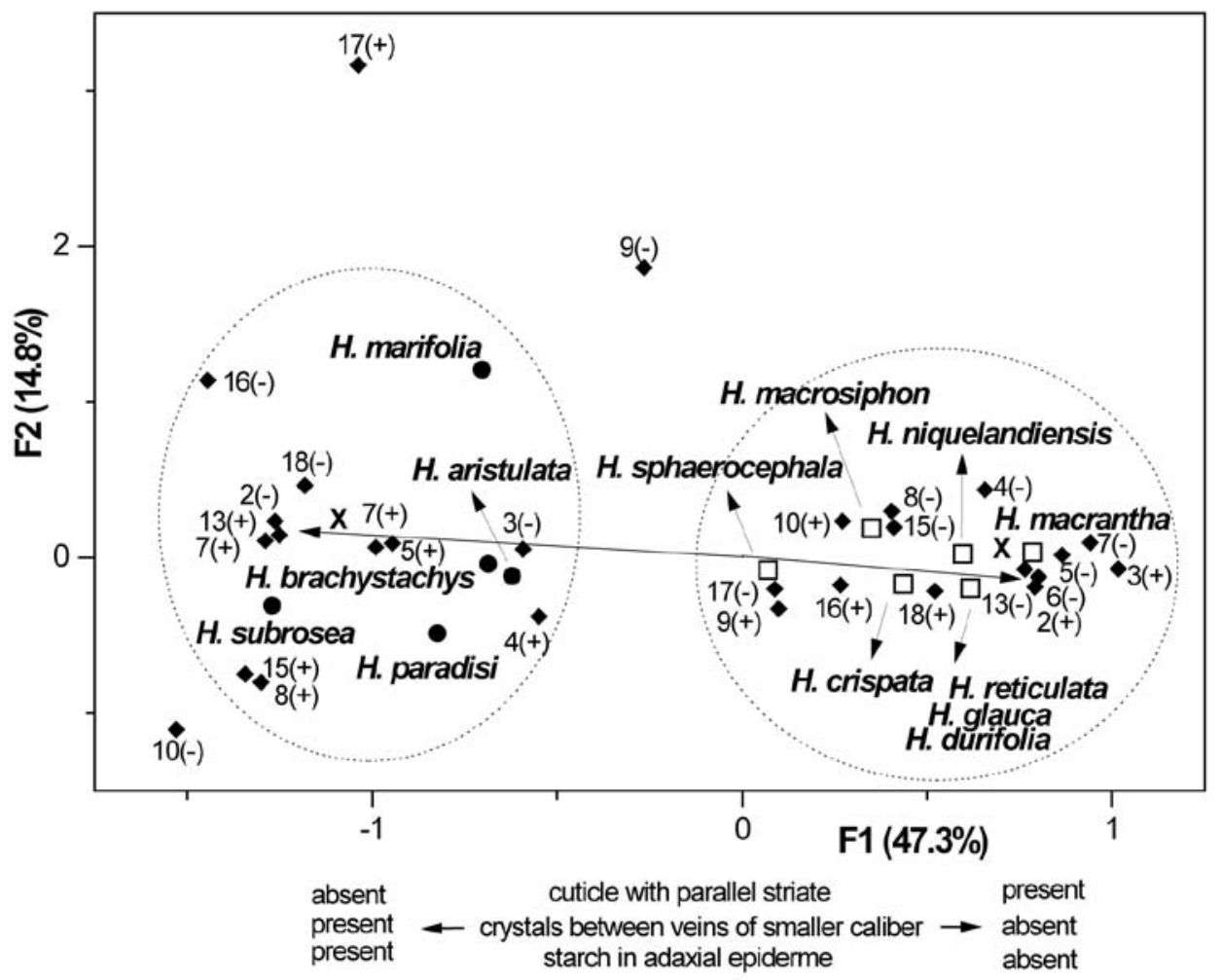

Figure S3. Biplot originating by multiple correspondence analysis of Hypenia spp. based on morphological and anatomical leaf characters to whose


represented as shaded losangles, and discriminant variables are highlighted as vectors from the origin. Crosses represent cluster centroids and values between parentheses refer to the explained variance on each principal component. 


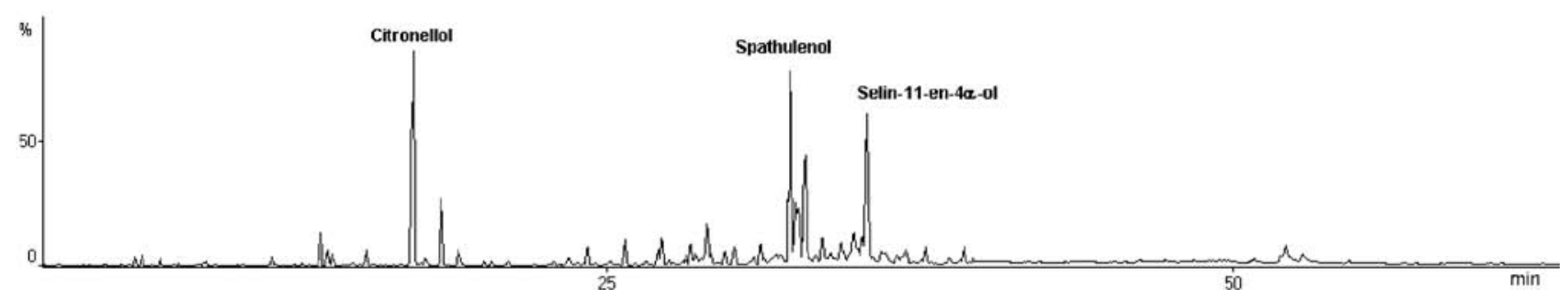

Figure S4. Total ion chromatogram of essential oil from H. brachystachys.

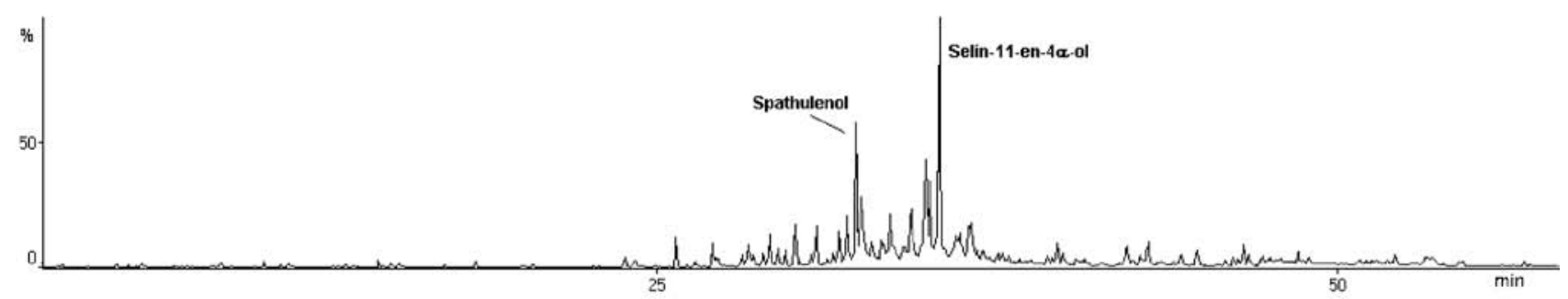

Figure S5. Total ion chromatogram of essential oil from H. aristulata.

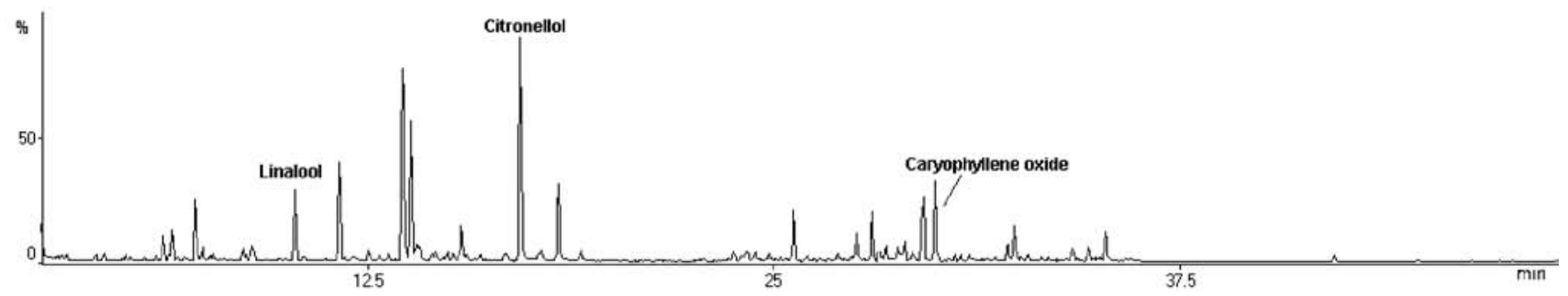

Figure S6. Total ion chromatogram of essential oil from H. marifolia.

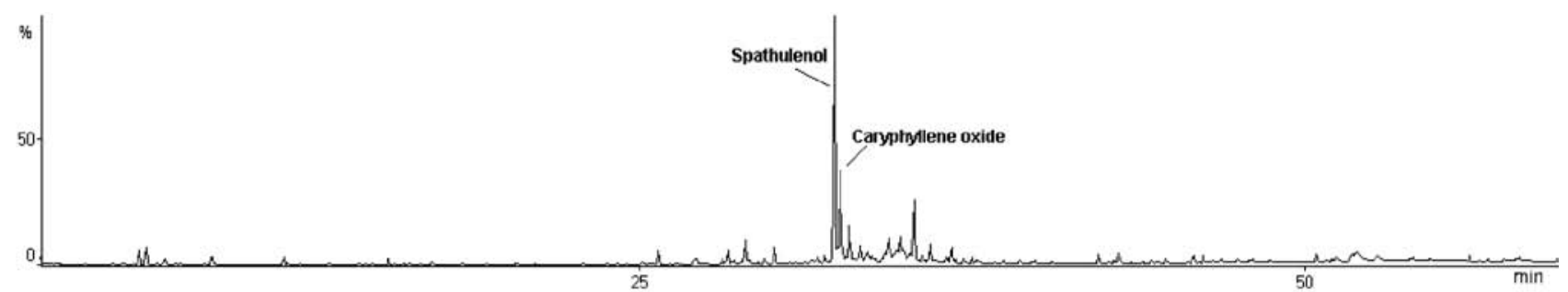

Figure S7. Total ion chromatogram of essential oil from $H$. paradise. 




Figure S8. Total ion chromatogram of essential oil from $H$. subrosea.

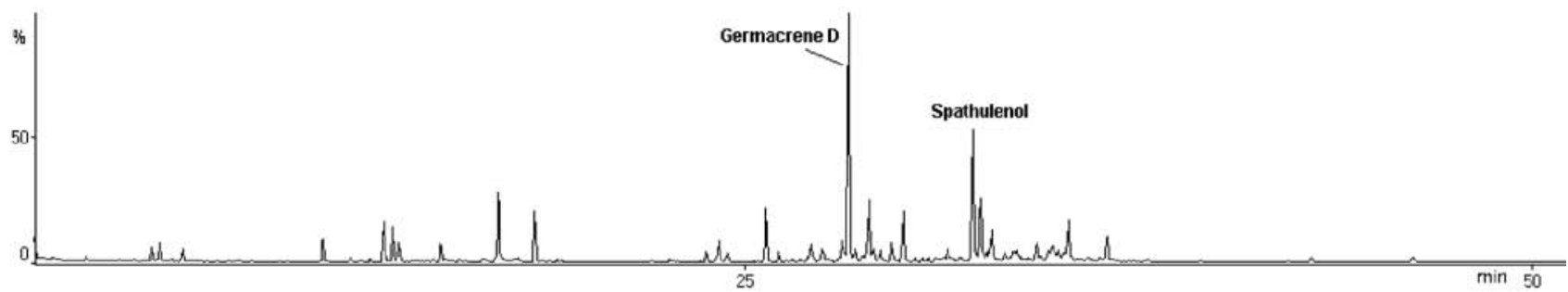

Figure S9. Total ion chromatogram of essential oil from H. crispata.

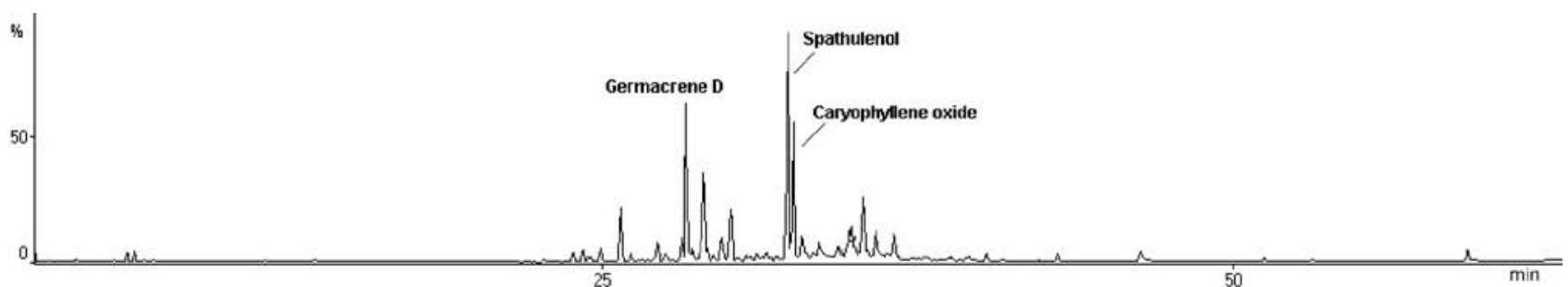

Figure S10. Total ion chromatogram of essential oil from H. durifolia.

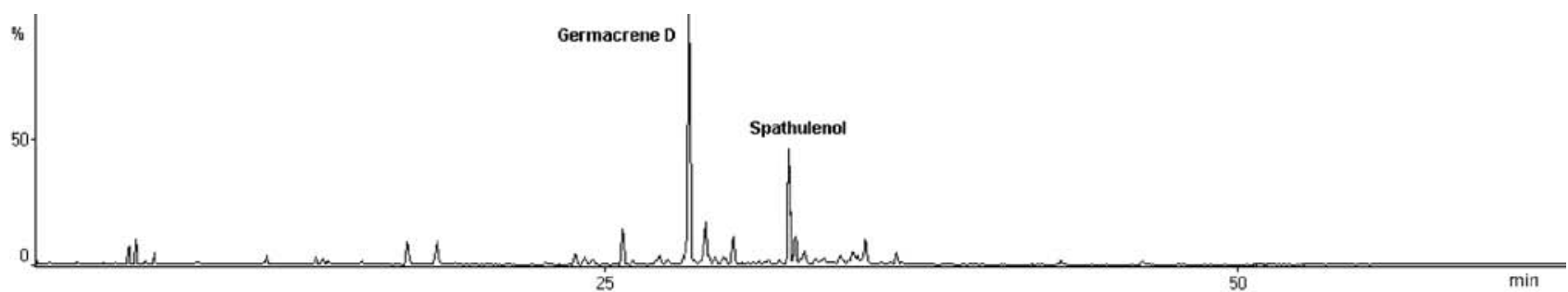

Figure S11. Total ion chromatogram of essential oil from H. glauca. 


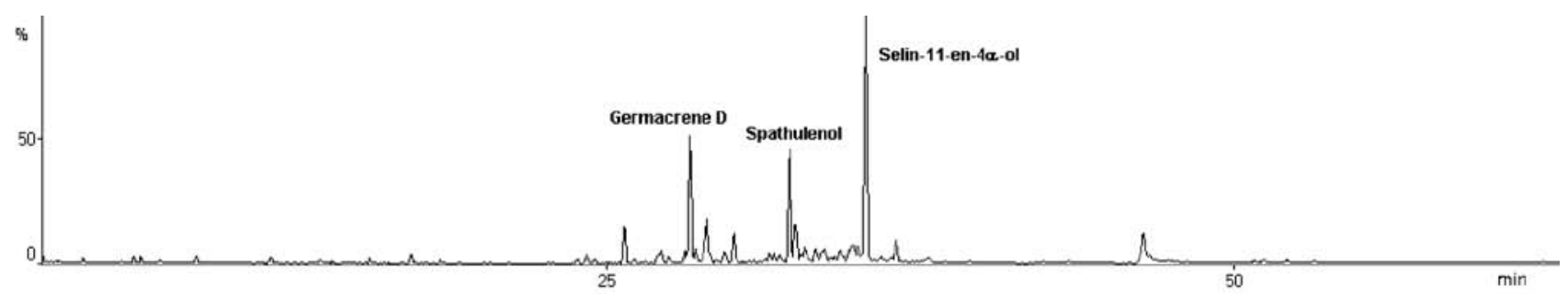

Figure S12. Total ion chromatogram of essential oil from H. macrantha.

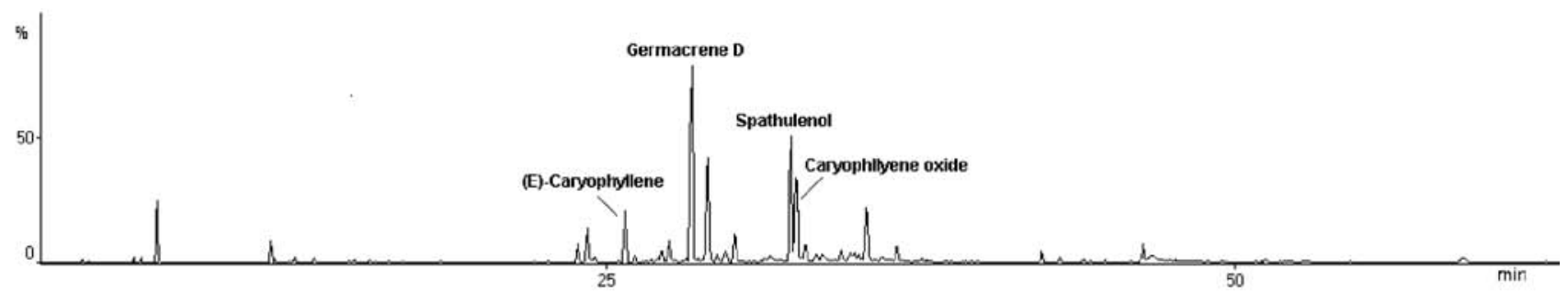

Figure S13. Total ion chromatogram of essential oil from H. macrosiphon.

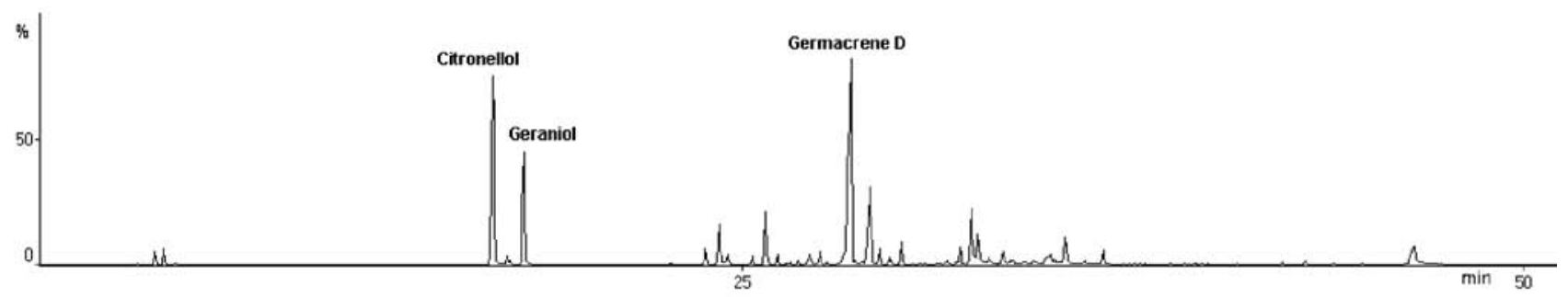

Figure S14. Total ion chromatogram of essential oil from H. niquelandiensis.

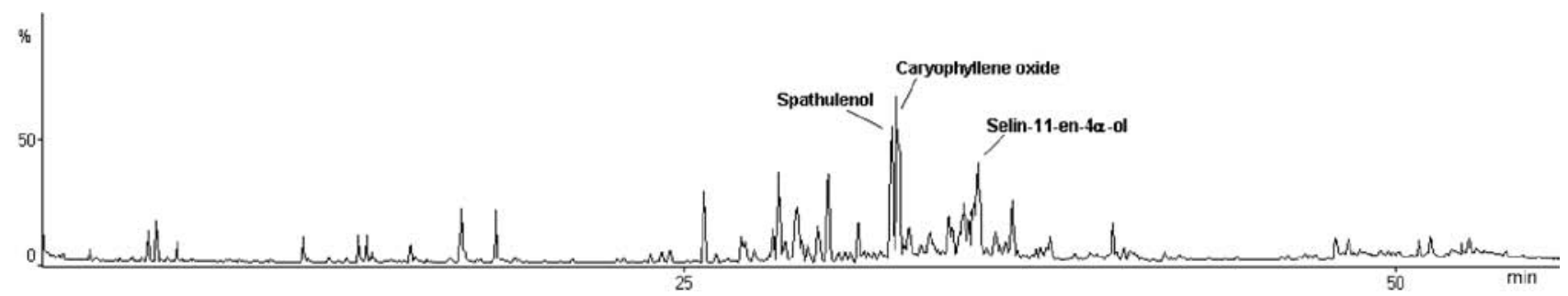

Figure S15. Total ion chromatogram of essential oil from H. reticulata. 


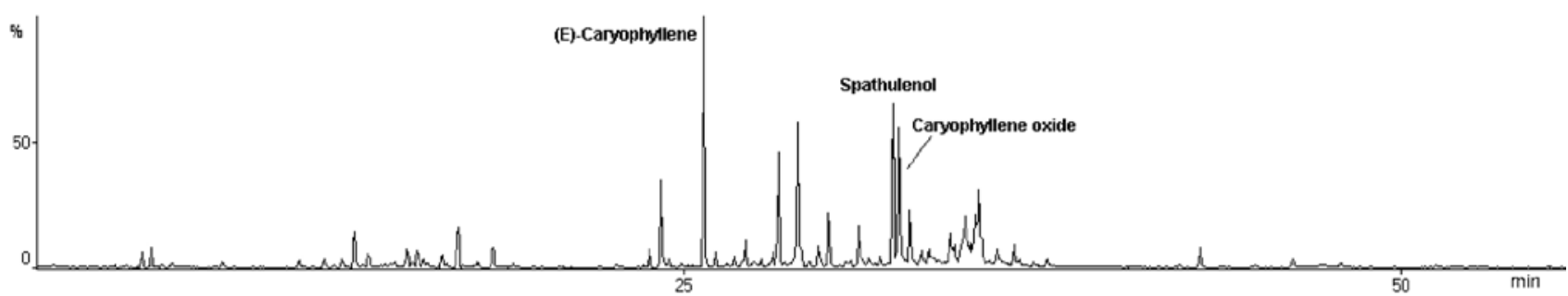

Figure S16. Total ion chromatogram of essential oil from H. sphaerocephala.


Figure S17. Total ion chromatogram of standards.



Figure S18. Total ion chromatogram of sage clary essential oil.

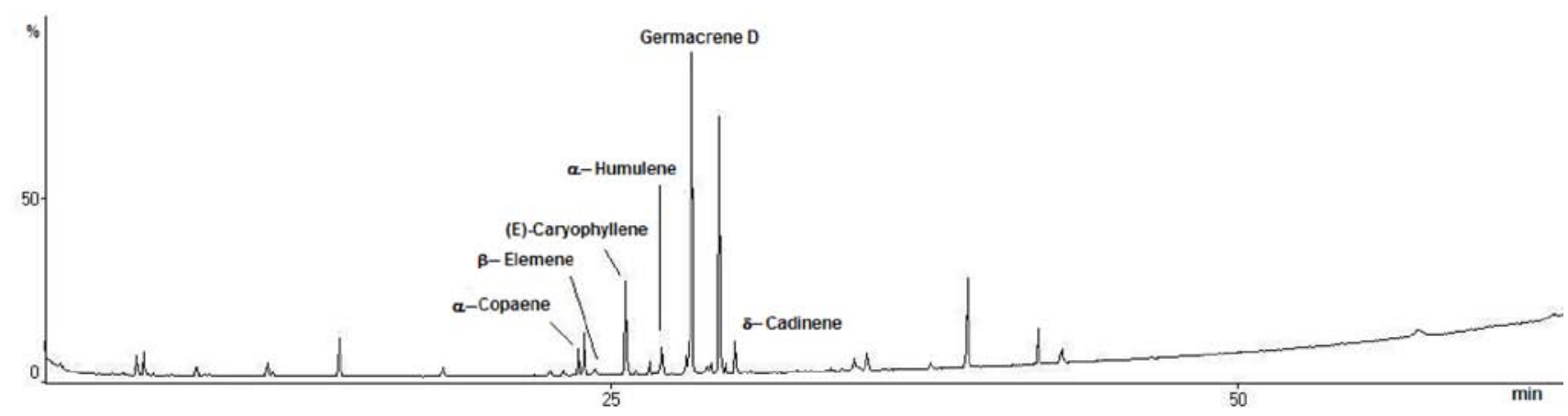

Figure S19. Total ion chromatogram of ylang-ylang essential oil. 


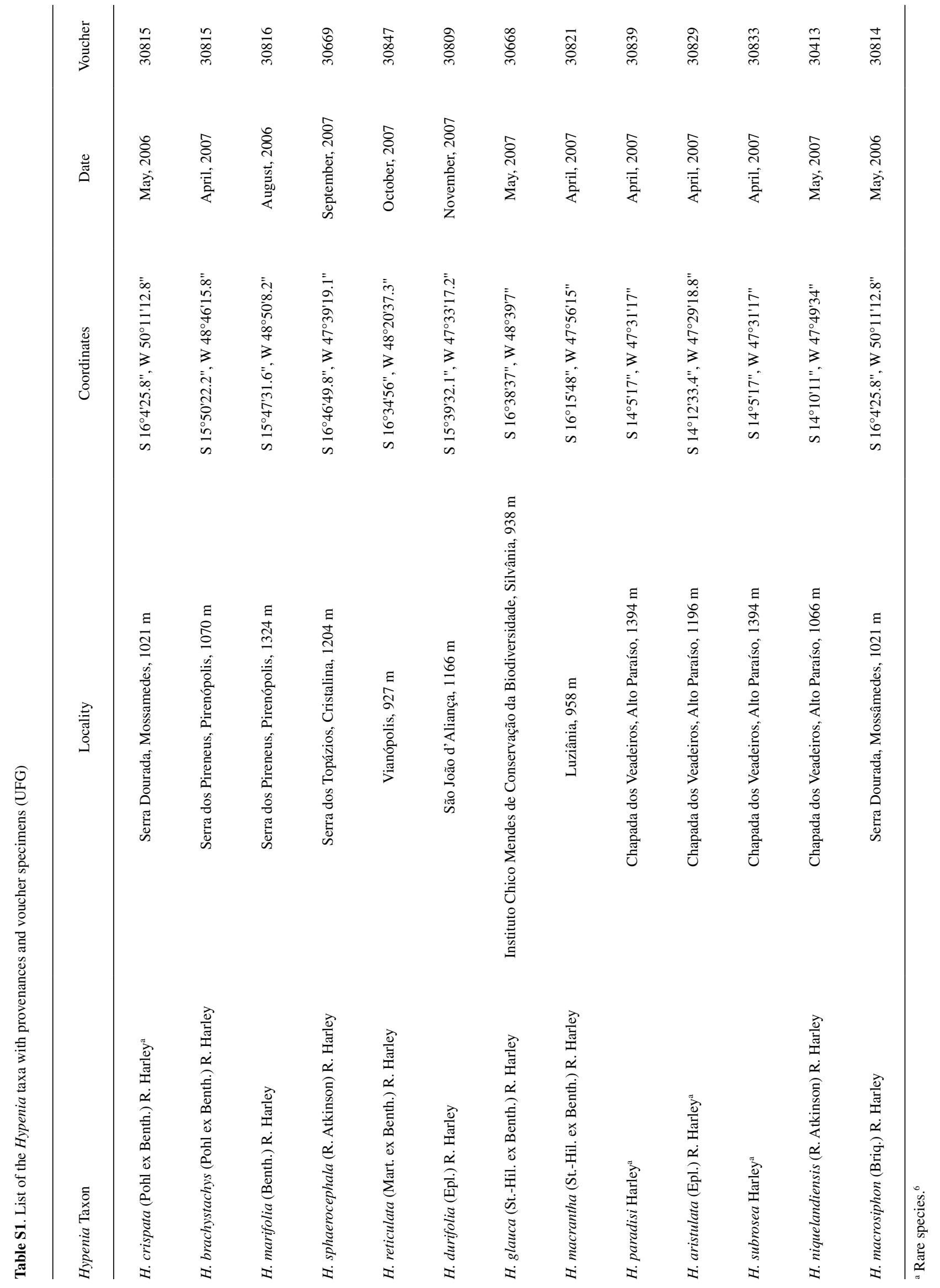




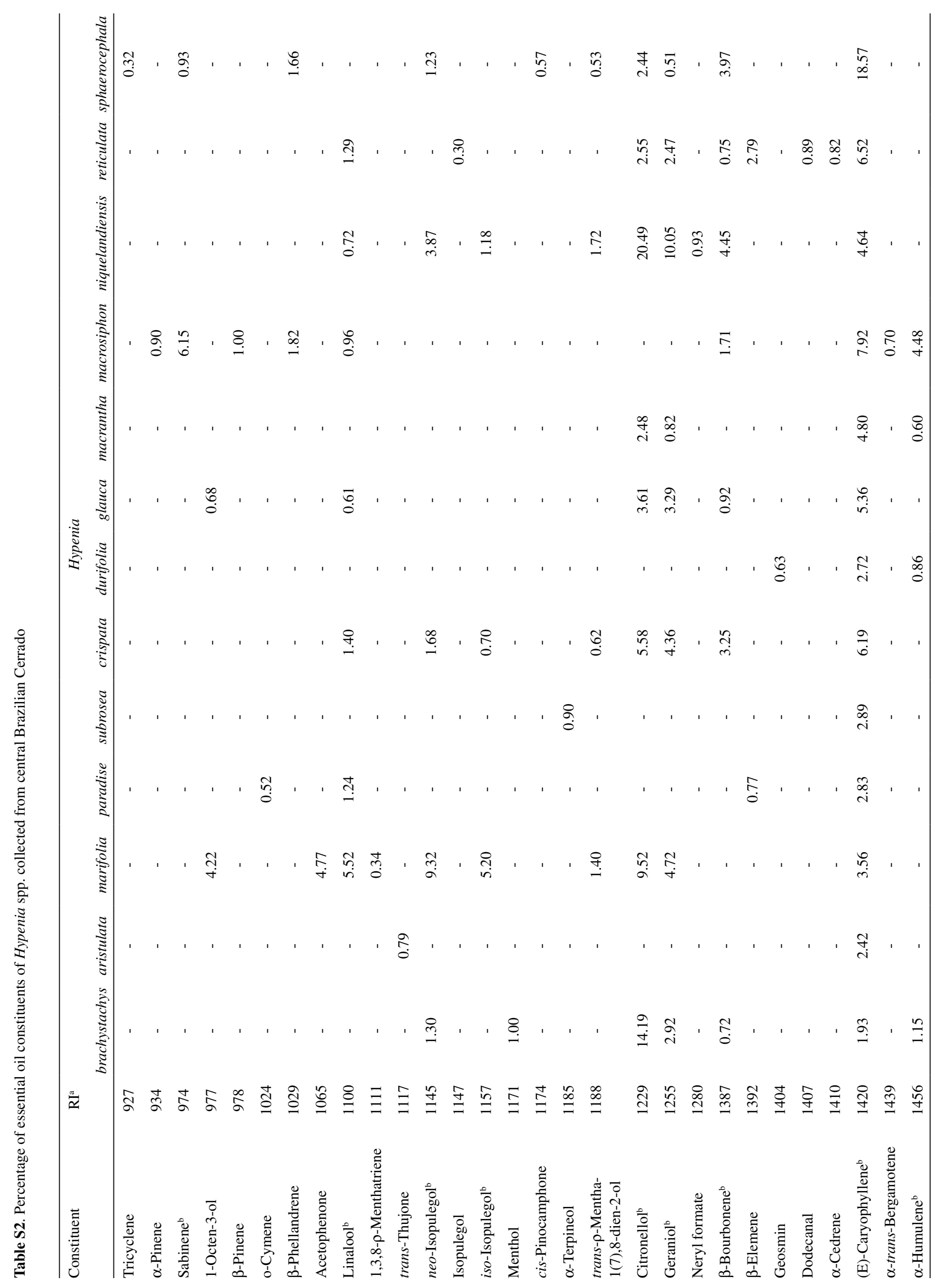




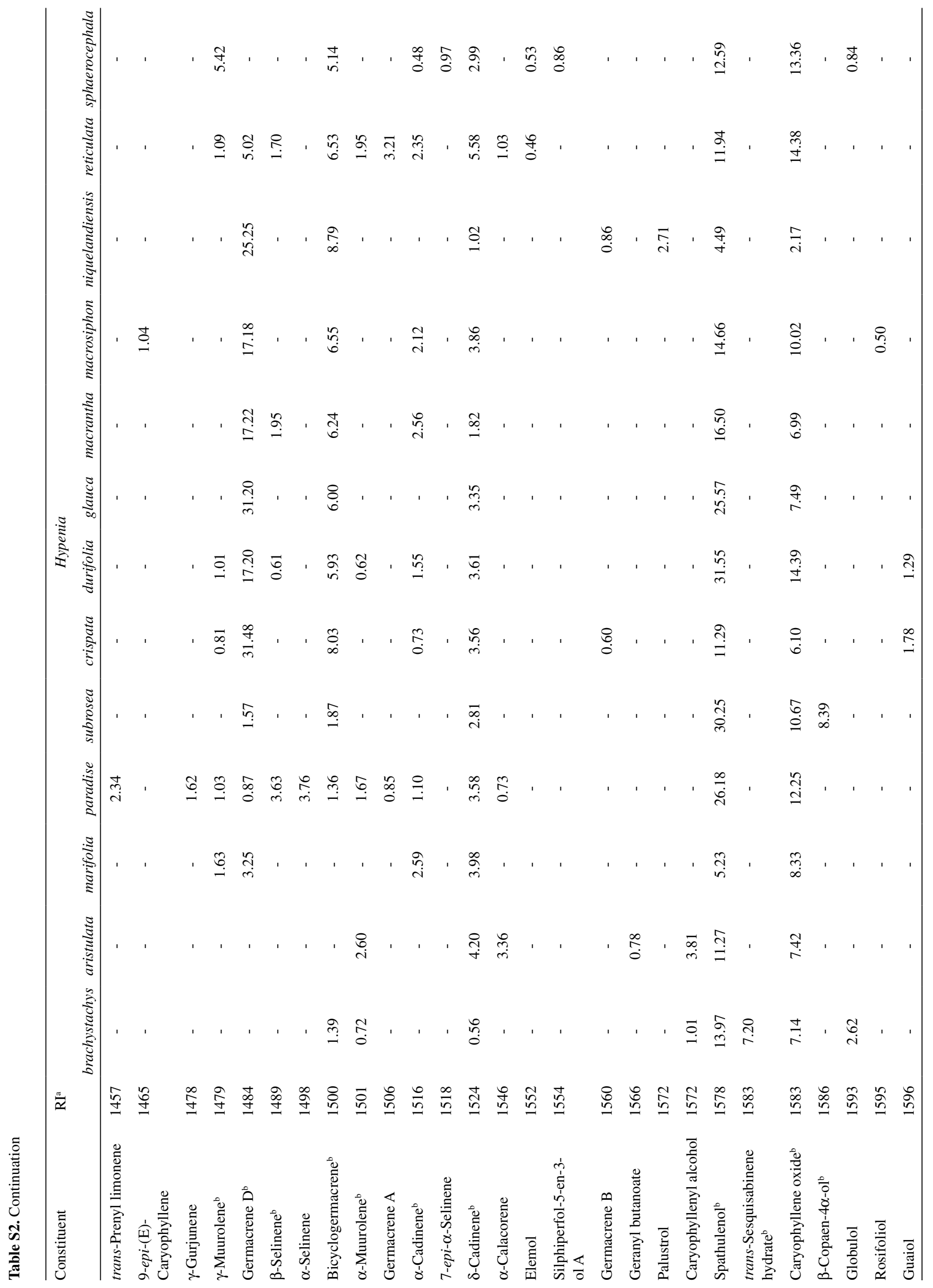




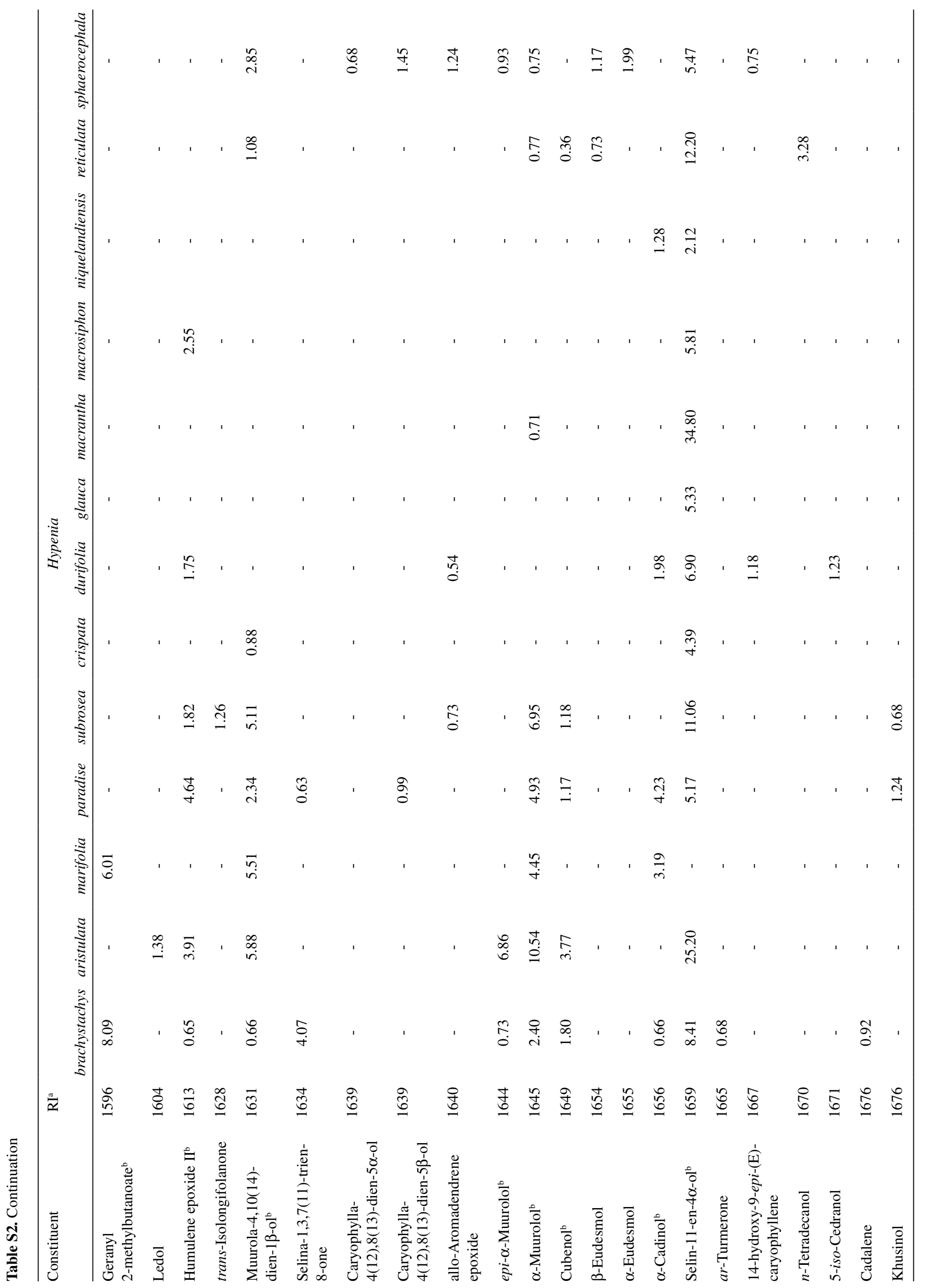




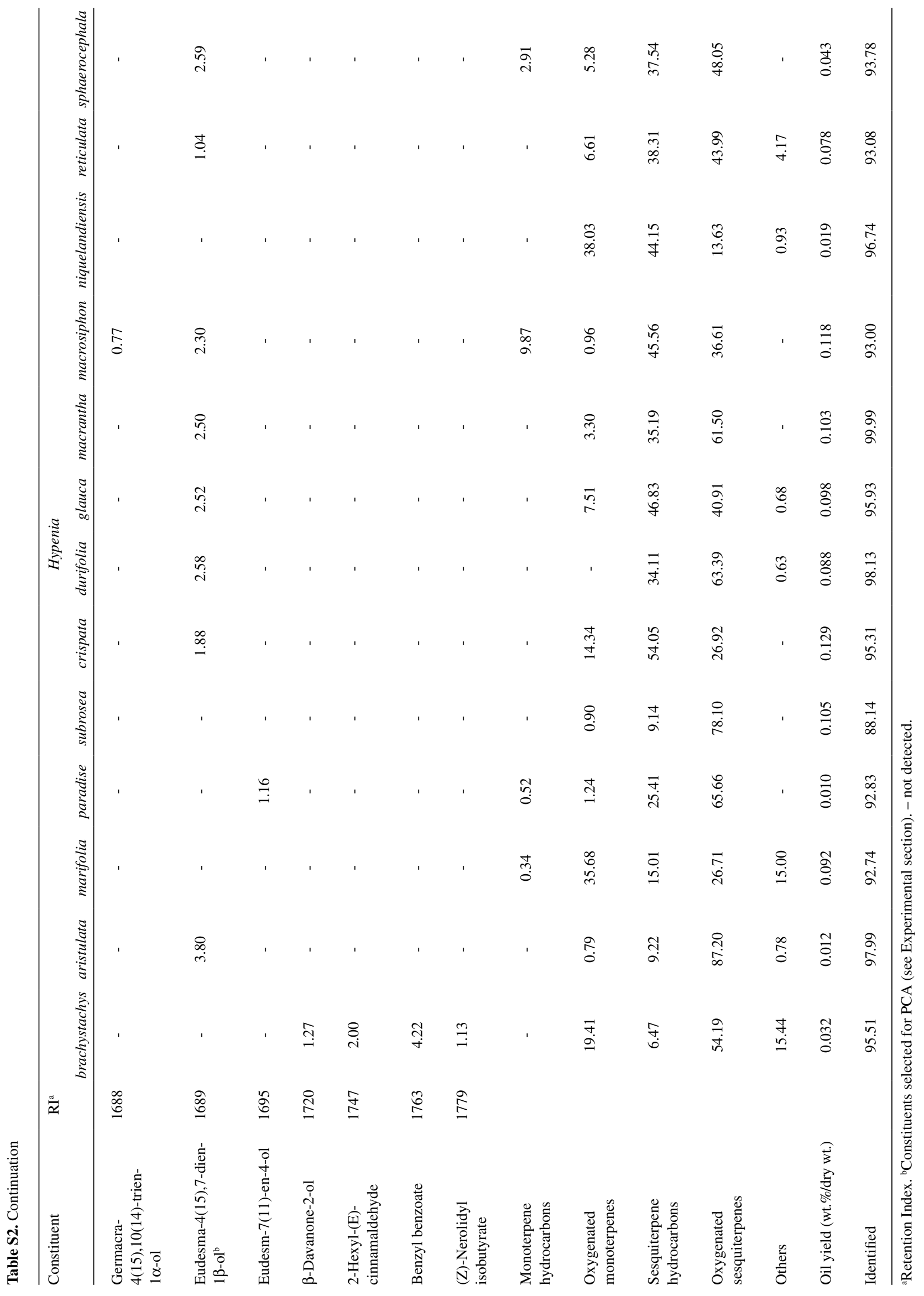


Table S3. Percentage ${ }^{a}$ of essential oils of clustered Hypenia spp. from central Brazilian Cerrado

\begin{tabular}{|c|c|c|c|c|c|}
\hline & Constituent & $\mathrm{RI}^{\mathrm{b}}$ & $\mathrm{RI}^{\mathrm{c}}$ & Cluster I & Cluster II \\
\hline 1 & Tricyclene & 927 & 921 & - & $0.04 \pm 0.11$ \\
\hline 2 & $\alpha$-Pinene & 934 & 932 & - & $0.11 \pm 0.32$ \\
\hline 3 & Sabinene & 974 & 969 & - & $0.89 \pm 2.15$ \\
\hline 4 & 1-Octen-3-ol ${ }^{\mathrm{d}}$ & 977 & 974 & $0.84 \pm 1.89 \mathrm{a}$ & $0.09 \pm 0.24 \mathrm{a}$ \\
\hline 5 & $\beta$-Pinene & 978 & 974 & - & $0.13 \pm 0.35$ \\
\hline 6 & o-Cymene & 1024 & 1022 & $0.10 \pm 0.23$ & - \\
\hline 7 & $\beta$-Phellandrene & 1029 & 1025 & - & $0.44 \pm 0.81$ \\
\hline 8 & Acetophenone & 1065 & 1065 & $0.95 \pm 2.13$ & - \\
\hline 9 & Linalool $^{\mathrm{e}}$ & 1100 & 1095 & $1.35 \pm 2.39 \mathrm{a}$ & $0.62 \pm 0.58 \mathrm{a}$ \\
\hline 10 & $1,3,8-\rho$-Menthatriene & 1111 & 1108 & $0.07 \pm 0.15$ & - \\
\hline 11 & trans-Thujone & 1117 & 1112 & $0.16 \pm 0.35$ & - \\
\hline 12 & neo-Isopulegole & 1145 & 1144 & $2.12 \pm 4.06 \mathrm{a}$ & $0.85 \pm 1.39 \mathrm{a}$ \\
\hline 13 & Isopulegol & 1147 & 1145 & - & $0.04 \pm 0.11$ \\
\hline 14 & iso-Isopulegole $^{\mathrm{e}}$ & 1157 & 1155 & $0.18 \pm 0.40$ & $0.24 \pm 0.45 \mathrm{a}$ \\
\hline 15 & Menthol & 1171 & 1167 & $0.28 \pm 0.63 \mathrm{a}$ & - \\
\hline 16 & cis-Pinocamphone & 1174 & 1172 & $4.74 \pm 6.70 \mathrm{a}$ & $0.07 \pm 0.20$ \\
\hline 17 & -Terpineol & 1185 & 1186 & $0.18 \pm 0.40$ & - \\
\hline 18 & trans- $\rho$-Mentha-1(7),8-dien-2-ol & 1188 & 1187 & $0.28 \pm 0.63 \mathrm{a}$ & $0.36 \pm 0.61 \mathrm{a}$ \\
\hline 19 & Citronellol & 1229 & 1223 & $4.74 \pm 6.70 \mathrm{a}$ & $4.64 \pm 6.66 \mathrm{a}$ \\
\hline 20 & Geraniol & 1255 & 1249 & $1.53 \pm 2.19 \mathrm{a}$ & $2.69 \pm 3.38 \mathrm{a}$ \\
\hline 21 & Neryl formate & 1280 & 1280 & - & $0.12 \pm 0.33$ \\
\hline 22 & $\beta$-Bourbonene $e^{e}$ & 1387 & 1387 & $0.14 \pm 0.32 b$ & $1.88 \pm 1.78 \mathrm{a}$ \\
\hline 23 & $\beta$-Elemene ${ }^{e}$ & 1392 & 1389 & $0.15 \pm 0.34 \mathrm{a}$ & $0.35 \pm 0.99 \mathrm{a}$ \\
\hline 24 & Geosmin & 1404 & 1399 & - & $0.08 \pm 0.22$ \\
\hline 25 & Dodecanal & 1407 & 1408 & - & $0.11 \pm 0.31$ \\
\hline 26 & $\alpha$-Cedrene & 1410 & 1410 & - & $0.10 \pm 0.29$ \\
\hline 27 & (E)-Caryophyllene $\mathrm{d}^{\mathrm{d}}$ & 1420 & 1417 & $2.73 \pm 0.60 \mathrm{~b}$ & $7.09 \pm 4.88 \mathrm{a}$ \\
\hline 28 & $\alpha$-trans-Bergamotene & 1439 & 1432 & - & $0.09 \pm 0.25$ \\
\hline 29 & $\alpha$-Humulene $e^{\mathrm{e}}$ & 1456 & 1452 & $0.23 \pm 0.51 \mathrm{a}$ & $0.74 \pm 1.55 \mathrm{a}$ \\
\hline 30 & trans-Prenyl limonene & 1457 & 1457 & $0.47 \pm 1.05$ & - \\
\hline 31 & 9-epi-(E)-Caryophyllene & 1465 & 1464 & - & $0.13 \pm 0.37$ \\
\hline 32 & $\gamma$-Gurjunene & 1478 & 1475 & $0.32 \pm 0.72$ & - \\
\hline 33 & $\gamma$-Muurolene & 1479 & 1478 & $0.53 \pm 0.76 \mathrm{a}$ & $1.04 \pm 1.83 \mathrm{a}$ \\
\hline 34 & Germacrene $\mathrm{D}^{\mathrm{e}}$ & 1484 & 1484 & $1.14 \pm 1.35 \mathrm{~b}$ & $18.1 \pm 11.4 \mathrm{a}$ \\
\hline 35 & $\beta$-Selinene & 1489 & 1489 & $0.73 \pm 1.62 \mathrm{a}$ & $0.53 \pm 0.83 \mathrm{a}$ \\
\hline 36 & $\alpha$-Selinene & 1498 & 1498 & $0.75 \pm 1.68$ & - \\
\hline 37 & Bicyclogermacrene & 1500 & 1500 & $0.92 \pm 0.87 \mathrm{~b}$ & $6.65 \pm 1.19 \mathrm{a}$ \\
\hline 38 & $\alpha$-Muurolene & 1501 & 1500 & $1.00 \pm 1.13 \mathrm{a}$ & $0.32 \pm 0.69 \mathrm{a}$ \\
\hline 39 & Germacrene $\mathrm{A}^{\mathrm{e}}$ & 1506 & 1508 & $0.17 \pm 0.38 \mathrm{a}$ & $0.40 \pm 1.13 \mathrm{a}$ \\
\hline 40 & $\alpha$-Cadinene & 1516 & 1513 & $0.74 \pm 1.14 \mathrm{a}$ & $1.22 \pm 1.05 \mathrm{a}$ \\
\hline 41 & 7-epi- $\alpha$-Selinene & 1518 & 1520 & - & $0.12 \pm 0.34$ \\
\hline 42 & $\delta$-Cadinene & 1524 & 1522 & $3.03 \pm 1.48 \mathrm{a}$ & $3.22 \pm 1.37 \mathrm{a}$ \\
\hline 43 & $\alpha$-Calacorene $e^{\mathrm{e}}$ & 1546 & 1544 & $0.82 \pm 1.46 \mathrm{a}$ & $0.13 \pm 0.36 \mathrm{a}$ \\
\hline 44 & Elemol & 1552 & 1548 & - & $0.12 \pm 0.23$ \\
\hline 45 & Silphiperfol-5-en-3-ol A & 1554 & 1557 & - & $0.11 \pm 0.30$ \\
\hline 46 & Germacrene B & 1560 & 1559 & - & $0.18 \pm 0.34$ \\
\hline 47 & Geranyl butanoate & 1566 & 1562 & $0.16 \pm 0.35$ & - \\
\hline 48 & Palustrol & 1572 & 1567 & - & $0.34 \pm 0.96$ \\
\hline 49 & Caryophyllenyl alcohol & 1572 & 1570 & $0.96 \pm 1.65$ & - \\
\hline
\end{tabular}


Table S3. Continuation

\begin{tabular}{|c|c|c|c|c|c|}
\hline & Constituent & $\mathrm{RI}^{\mathrm{b}}$ & $\mathrm{RI}^{\mathrm{c}}$ & Cluster I & Cluster II \\
\hline 50 & Spathulenol & 1578 & 1577 & $17.4 \pm 10.5 \mathrm{a}$ & $16.1 \pm 8.60 \mathrm{a}$ \\
\hline 51 & trans-Sesquisabinene hydrate & 1583 & 1577 & $1.44 \pm 3.22$ & - \\
\hline 52 & Caryophyllene oxide & 1583 & 1582 & $9.16 \pm 2.22 \mathrm{a}$ & $9.36 \pm 4.45 \mathrm{a}$ \\
\hline 53 & $\beta$-Copaen- $4 \alpha$-ol & 1586 & 1590 & $1.68 \pm 3.75$ & - \\
\hline 54 & Globulol $^{\mathrm{e}}$ & 1593 & 1590 & $0.52 \pm 1.17 \mathrm{a}$ & $0.11 \pm 0.30 \mathrm{a}$ \\
\hline 55 & Rosifoliol & 1595 & 1600 & - & $0.06 \pm 0.18$ \\
\hline 56 & Guaiol & 1596 & 1600 & - & $0.38 \pm 0.72$ \\
\hline 57 & Geranyl 2-methylbutanoate & 1596 & 1601 & $2.82 \pm 3.93$ & - \\
\hline 58 & Ledol & 1604 & 1602 & $0.28 \pm 0.62$ & - \\
\hline 59 & Humulene epoxide II & 1613 & 1608 & $2.20 \pm 2.02 \mathrm{a}$ & $0.54 \pm 1.02 \mathrm{a}$ \\
\hline 60 & trans-Isolongifolanone & 1628 & 1625 & $0.25 \pm 0.56$ & - \\
\hline 61 & Muurola-4,10(14)-dien-1 $\beta$-ol & 1631 & 1630 & $3.90 \pm 2.29 \mathrm{a}$ & $0.60 \pm 1.01 \mathrm{~b}$ \\
\hline 62 & Selina-1,3,7(11)-trien-8-one & 1634 & 1632 & $0.94 \pm 1.77$ & - \\
\hline 63 & Caryophylla-4(12),8(13)-dien-5 $\alpha$-ol & 1639 & 1639 & - & $0.09 \pm 0.24$ \\
\hline 64 & Caryophylla-4(12),8(13)-dien-5 $\beta$-ol & 1639 & 1639 & $0.20 \pm 0.44 \mathrm{a}$ & $0.18 \pm 0.51 \mathrm{a}$ \\
\hline 65 & allo-Aromadendrene epoxide & 1640 & 1639 & $0.15 \pm 0.33 \mathrm{a}$ & $0.22 \pm 0.45 \mathrm{a}$ \\
\hline 66 & 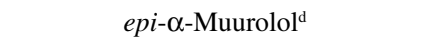 & 1644 & 1640 & $1.52 \pm 3.00 \mathrm{a}$ & $0.12 \pm 0.33 \mathrm{a}$ \\
\hline 67 & $\alpha$-Muurolol ${ }^{\mathrm{e}}$ & 1645 & 1644 & $5.85 \pm 3.08 \mathrm{a}$ & $0.28 \pm 0.39 \mathrm{~b}$ \\
\hline 68 & Cubenol & 1649 & 1645 & $1.58 \pm 1.38 \mathrm{a}$ & $0.05 \pm 0.13 b$ \\
\hline 69 & $\beta$-Eudesmol & 1654 & 1649 & - & $0.24 \pm 0.46$ \\
\hline 70 & $\alpha$-Eudesmol & 1655 & 1652 & - & $0.25 \pm 0.70$ \\
\hline 71 & $\alpha$-Cadinol & 1656 & 1652 & $1.62 \pm 1.97 \mathrm{a}$ & $0.41 \pm 0.78 \mathrm{a}$ \\
\hline 72 & Selin-11-en-4 $\alpha$-ol & 1659 & 1658 & $9.97 \pm 9.46 \mathrm{a}$ & $9.63 \pm 10.6 \mathrm{a}$ \\
\hline 73 & ar-Turmerone & 1665 & 1668 & $0.14 \pm 0.30$ & - \\
\hline 74 & 14-hydroxy-9-epi-(E)-caryophyllene & 1667 & 1668 & - & $0.24 \pm 0.46$ \\
\hline 75 & n-Tetradecanol & 1670 & 1671 & - & $0.41 \pm 1.16$ \\
\hline 76 & 5-iso-Cedranol & 1671 & 1672 & - & $0.15 \pm 0.43$ \\
\hline 77 & Cadalene & 1676 & 1675 & $0.18 \pm 0.41$ & - \\
\hline 79 & Khusinol $^{\mathrm{d}}$ & 1676 & 1679 & $0.38 \pm 0.56$ & - \\
\hline 80 & Germacra-4(15),10(14)-trien-1 $\alpha$-ol & 1688 & 1685 & - & $0.10 \pm 0.27$ \\
\hline 81 & Eudesma-4(15),7-dien-1 $\beta$-ol & 1689 & 1687 & $0.76 \pm 1.70 \mathrm{a}$ & $1.93 \pm 0.94 \mathrm{a}$ \\
\hline 82 & Eudesm-7(11)-en-4-ol & 1695 & 1700 & $0.23 \pm 0.52$ & - \\
\hline 83 & $\beta$-Davanone-2-ol & 1720 & 1718 & $0.25 \pm 0.57$ & - \\
\hline 84 & 2-Hexyl-(E)-cinnamaldehyde & 1747 & 1748 & $0.40 \pm 0.89$ & - \\
\hline 85 & Benzyl benzoate & 1763 & 1759 & $0.84 \pm 1.89$ & - \\
\hline$\underline{86}$ & (Z)-Nerolidyl isobutyrate & 1779 & 1783 & $0.23 \pm 0.51$ & - \\
\hline \multicolumn{4}{|c|}{ Monoterpene hydrocarbons ${ }^{\mathrm{d}}$} & $0.17 \pm 0.24 \mathrm{a}$ & $1.60 \pm 3.49 \mathrm{a}$ \\
\hline \multicolumn{4}{|c|}{ Oxygenated monoterpenes } & $11.6 \pm 15.7 \mathrm{a}$ & $9.50 \pm 12.4 \mathrm{a}$ \\
\hline \multicolumn{4}{|c|}{ Sesquiterpene hydrocarbons } & $13.1 \pm 7.6 \mathrm{~b}$ & $42.0 \pm 6.8 \mathrm{a}$ \\
\hline \multicolumn{4}{|c|}{ Oxygenated sesquiterpenes } & $62.4 \pm 23.5 \mathrm{a}$ & $41.9 \pm 16.7 \mathrm{a}$ \\
\hline \multicolumn{4}{|c|}{ Others $^{d}$} & $6.24 \pm 8.20 \mathrm{a}$ & $0.80 \pm 1.41 \mathrm{a}$ \\
\hline \multicolumn{4}{|c|}{ Identified constituents } & $93.4 \pm 3.7 \mathrm{a}$ & $95.8 \pm 2.5 \mathrm{a}$ \\
\hline
\end{tabular}

${ }^{\mathrm{a} A v e r a g e}$ based on original data. ${ }^{\mathrm{b}}$ Calculated Retention index. ${ }^{\mathrm{c}}$ Reported Retention index. ${ }^{32}{ }^{\mathrm{C}}$ Rank and ${ }^{\mathrm{e}}$ arcsine-transformed in ANOVA analysis (see Experimental section). - = not detected. Percentage values followed by the same letter in the rows did not share significant differences at $5 \%$ probability by Tukey's test. 


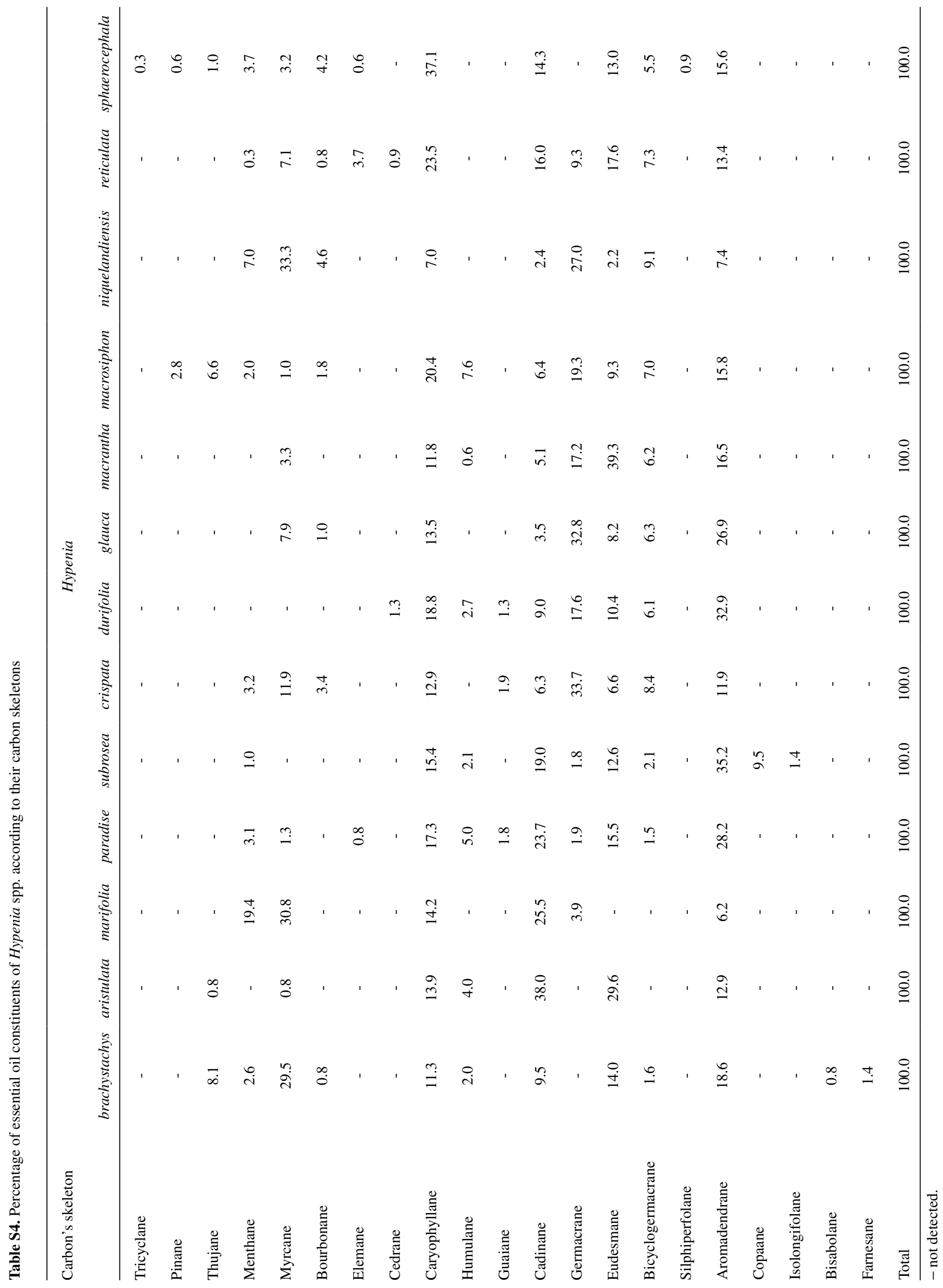


Table S5. Percentage ${ }^{a}$ of essential oil constituents of clustered Hypenia spp. according to carbon skeletons

\begin{tabular}{|c|c|c|}
\hline Carbon's skeleton & Cluster I & Cluster II \\
\hline Tricyclane & - & $0 \pm 0.1$ \\
\hline Pinane & - & $0.4 \pm 1.0$ \\
\hline Thujane & $1.8 \pm 3.5 \mathrm{a}$ & $1.0 \pm 2.3 \mathrm{a}$ \\
\hline Menthane $^{\mathrm{b}}$ & $5.2 \pm 8.0 \mathrm{a}$ & $2.0 \pm 2.5 \mathrm{a}$ \\
\hline Myrcane & $12.5 \pm 16.1 \mathrm{a}$ & $8.5 \pm 10.8 \mathrm{a}$ \\
\hline Bourbonane $^{b}$ & $0.2 \pm 0.4 b$ & $2.0 \pm 1.9 \mathrm{a}$ \\
\hline Elemane $^{b}$ & $0.2 \pm 0.4 \mathrm{a}$ & $0.5 \pm 1.3 b$ \\
\hline Cedrane & - & $0.3 \pm 0.5$ \\
\hline Caryophyllane $^{c}$ & $14.4 \pm 2.2 \mathrm{a}$ & $18.1 \pm 9.3 \mathrm{a}$ \\
\hline Humulane & $2.6 \pm 1.9 \mathrm{a}$ & $1.4 \pm 2.7 \mathrm{a}$ \\
\hline Guaiane & $0.4 \pm 0.8 \mathrm{a}$ & $0.4 \pm 0.8 \mathrm{a}$ \\
\hline Cadinane $^{\mathrm{b}}$ & $23.1 \pm 10.4 \mathrm{a}$ & $7.9 \pm 4.9 \mathrm{~b}$ \\
\hline Germacrane & $1.5 \pm 1.6 \mathrm{~b}$ & $19.6 \pm 11.5 \mathrm{a}$ \\
\hline Eudesmane & $14.3 \pm 10.5 \mathrm{a}$ & $13.3 \pm 11.4 \mathrm{a}$ \\
\hline Bicyclogermacrane & $1.0 \pm 1.0 \mathrm{~b}$ & $7.0 \pm 1.2 \mathrm{a}$ \\
\hline Silphiperfolane & - & $0.1 \pm 0.3$ \\
\hline Aromadendrane & $20.2 \pm 11.6 \mathrm{a}$ & $17.5 \pm 8.3 \mathrm{a}$ \\
\hline Copaane & $1.9 \pm 4.3$ & - \\
\hline Isolongifolane & $0.3 \pm 0.6$ & - \\
\hline Bisabolane & $0.2 \pm 0.3$ & - \\
\hline Farnesane & $0.3 \pm 0.6$ & - \\
\hline
\end{tabular}

${ }^{a}$ Average based on original data. ${ }^{b}$ Arcsine and crank-transformed in ANOVA analysis (see Experimental section). Percentage values followed by the same letter in the rows did not share significant differences at $5 \%$ probability by Tukey's test. - = not detected. 


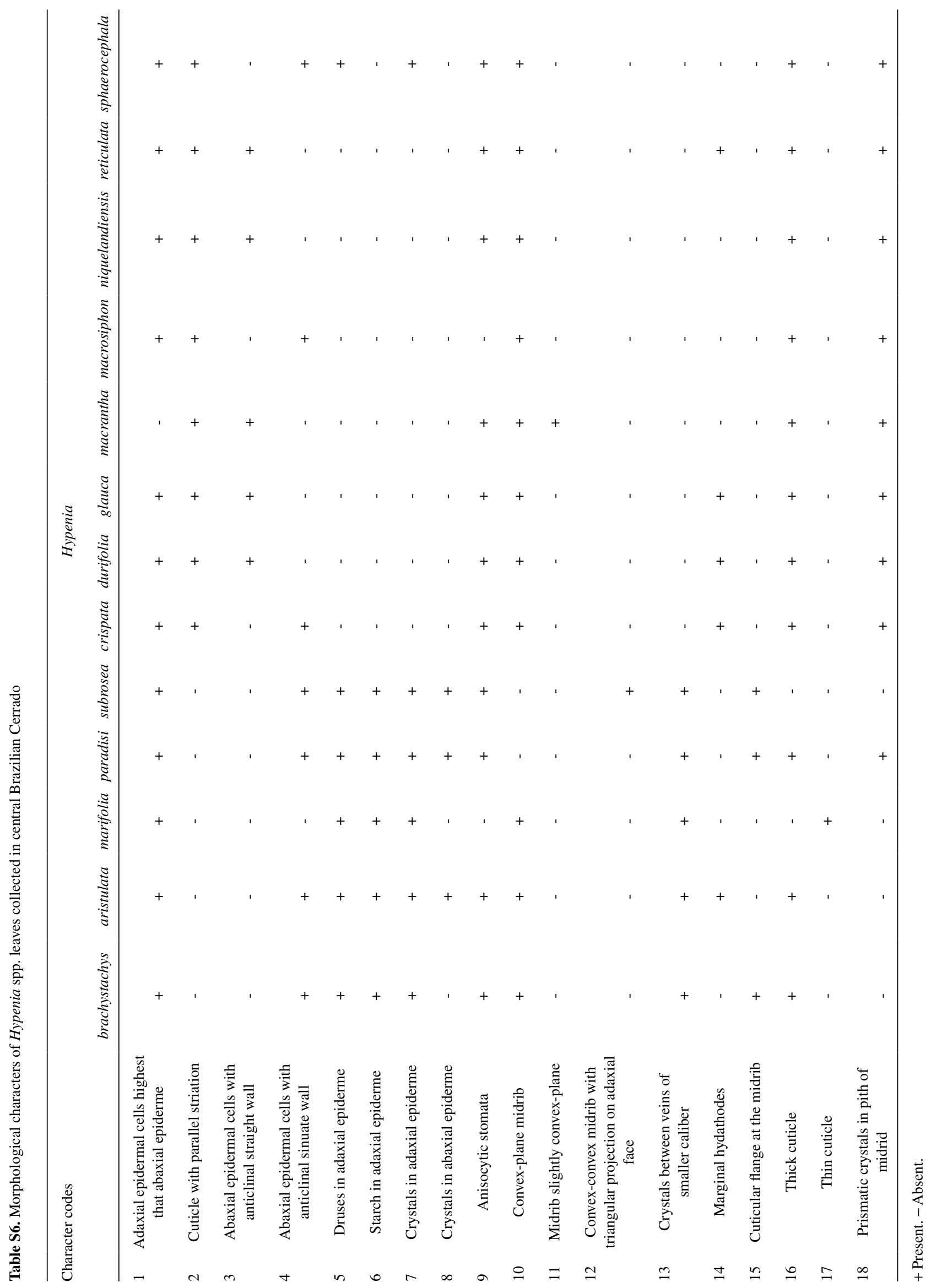

